\title{
"ECONOMIC STUDY FOR THE PRODUCTION AND MARKETING OF GARLIC CROP IN EGYPT (STUDY CASE FOR BENI SUEF GOVERNORATE)"
}

\author{
REHAB ATTIA HASHEM AWAD
}

\author{
Economic Research Institute
}

(Manuscript received 12 February 2019)

\begin{abstract}
$\mathrm{T}$ he garlic crop is an important export crop in Egypt, which occupies a prominent position among its export commodities. This comparative advantage makes Egypt highly competitive in the foreign markets for the export of garlic. Egyptian garlic is exported to Arab countries, African countries, Eastern and Western Europe countries. Egyptian garlic and these are new markets for this crop, and the garlic crop of strategic crops in the province of Beni Suef, which is grown in large areas and is considered a cash crop also, in addition to that can be loaded on other crops. Of the unit of land, garlic may be loaded on the cotton crop and sometimes cotton is grown in the presence of garlic to exploit the time factor and no delay in the cultivation of the cotton crop and get good results and may be loaded with the harvest of the crop and the area cultivated with garlic during the agricultural season 2016/2017 The level of the Republic of 29242 feddans, while the cultivated area of the province amounted to 11103 acres, representing about $37.96 \%$ of the area cultivated at the level of the Republic .
\end{abstract}

The problem of the study: There was a significant variation in the cultivated area, as well as the agricultural price, both at the national level or in the governorate of Beni Suef, as well as a difference in the centers of the province - which led to the decline of Egyptian garlic exports in the global markets due to the decline in demand and therefore it was necessary exposure The aim of the study is to identify the current status of production and marketing of garlic crop in Beni Suef governorate to identify the most important factors for the production process, as well as study the marketing pathways to identify the most important production and marketing problems. T-crop farmers face and how to overcome them or reduce them. Methods of study Sources of data acquisition: A set of statistical methods and methods were used to analyze the data, which is consistent with the nature of the data collected and the objective of the research. The data were obtained from two main sources: first, secondary data obtained from the Ministry of Agriculture, Central data center for public mobilization and statistics and the Directorate of Agriculture in Beni Suef, and second: preliminary data obtained from a case study conducted in Beni Suef for garlic crop in the agricultural season 2016/2017. The most important results: The area planted with garlic crop at the level of The yield area of the crop was estimated at 24.567 feddans while the cultivated area of the crop in Beni Suef governorate showed a general and increasing trend at $0.01 \%$, estimated at 1032 feddans and with an annual change rate of 1.88 
The general time trend equation indicates that the Feddan costs have increased by a statistically significant increase of about LE 200 per feddan with an annual change rate of $4.5 \%$. Whereas the cost of the garlic crop in the governorate of Beni Suef took a general trend of increasing and statistical significance of about 100 pounds / fed and an annual rate of change of about $1.75 \%$. The average consumption of garlic in Egypt was estimated at 264,311 tons during the period (2001 - 2016), while the average of garlic production in Egypt was estimated at 264.5 thousand tons. The average volume of imports during the study period was about 6.125 thousand tons. As for the exports of the garlic crop, it was found that the average volume of garlic exports during the study period was estimated at 8.938 thousand tons - while the average consumption of garlic was estimated at 229.438 thousand tons. The garlic crop in Egypt has grown to 34.25 thousand tons during the period of study Of. The average per capita share of the garlic crop in the Arab Republic of Egypt during the study period (2001 2016) showed that there was a significant statistical decrease of about $0.576 \mathrm{~kg} /$ person / year with an annual change rate of about $18.9 \%$ of the average annual per capita. The results of estimating the function of the cost of producing the garlic crop at the sample level: The lowest volume of the production cost amounted to about 8.342 tons per feddan while the optimum size for the maximum production of profit is 11.07 tons per feddan. The statistical estimation of the physical function of the garlic crop showed that there was a positive relationship between the quantity of garlic crop per ton per feddan and human labor, chemical fertilizer and pesticides as independent variables, while there was an inverse relation between the quantity produced from garlic and the municipal fertilizer. The results of the study sample showed that there are several productivity problems. The most important productivity problems are: high prices of chemical fertilizers, high seed value, high value of human labor, high cost of automation, cost of pesticides, representing $74.9 \%, 51 \%, 46.9 \%, 40.9 \%$ and $13 \%$, respectively, according to the opinion of the farmers of the sample of the study. As for the marketing problems, it came as follows: The failure of the agricultural association to play a role in marketing, fluctuation of the price of the crop, the difference in price between farms and traders, A certain entity responsible for marketing, the monopoly of local traders for marketing, inadequate Marketing information, high transport costs, $78.3 \%, 71 \%, 62 \%$, $61.5 \%, 57.8 \%, 51.8 \%, 50 \%$ and $48 \%$, respectively, according to the views of the sample farmers. 


\title{
" در اسة اقتصادية لإتتاج وتسويق محصول الثوم في مصر

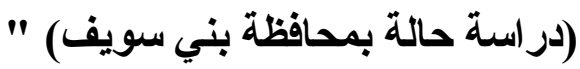

\author{
رحاب عطية هاثم
}

\section{مقدمة}

معرج بحوث الاقتصاد الزراعي - معر

الثوم من محاصيل الخضر التي تزرع بمصر بالعروة الثنتية خلال شهري سبتمبر و أكتوبر

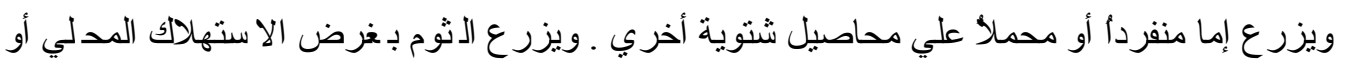

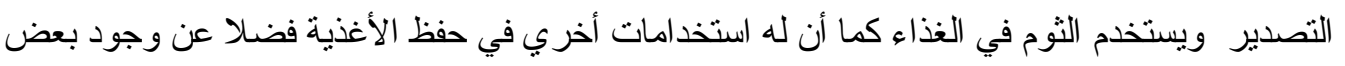
الاستخدامات الطبية له .

ويعد الثوم من المحاصيل التصديرية الهامة سو اء للأسواق العربية أو الأوروبية ويصدر الثوم

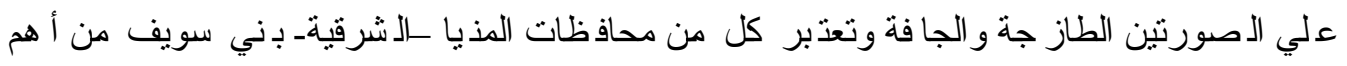

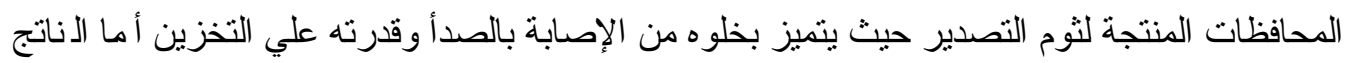

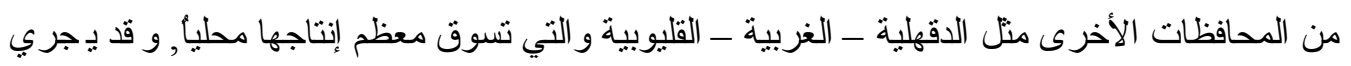

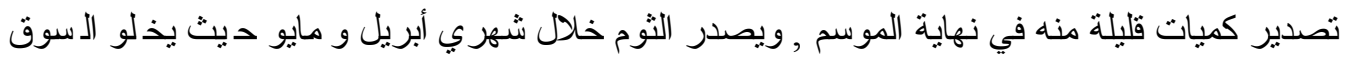

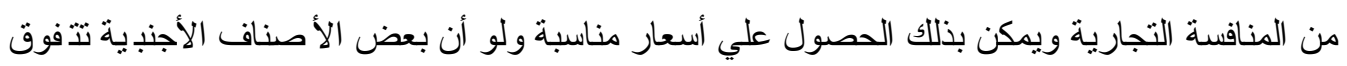

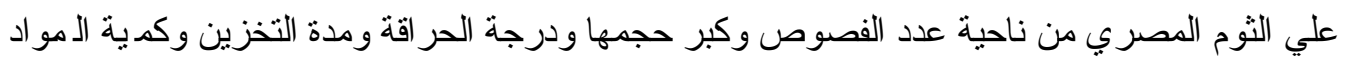

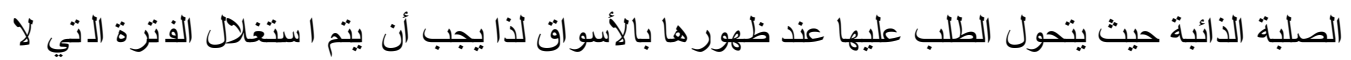

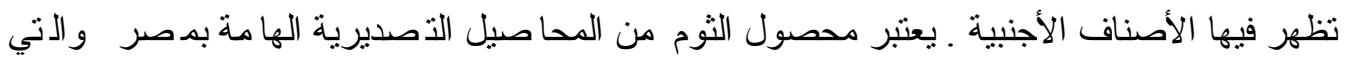

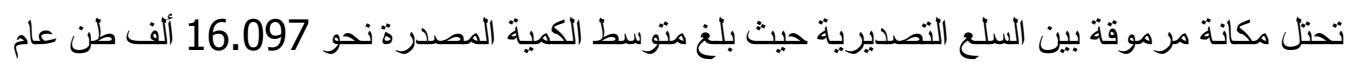

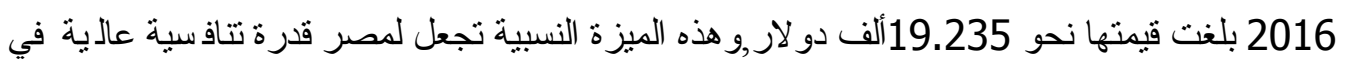
الأسواق الخارجية بالنسبة لتصدير الثوم , ويصدر الثوم المصري إلى الدول العربية و الدول الأفريقية

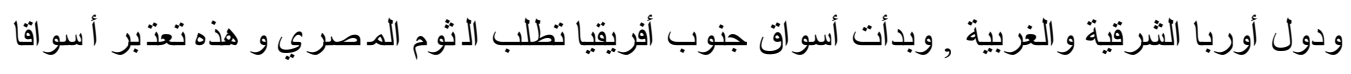

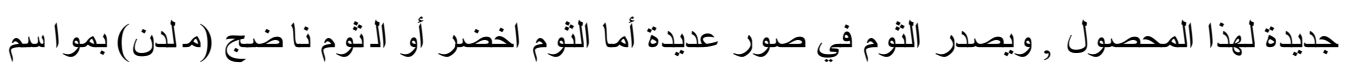

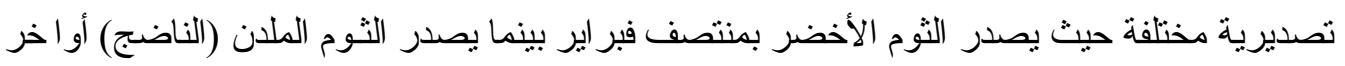

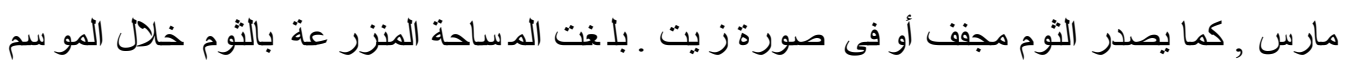

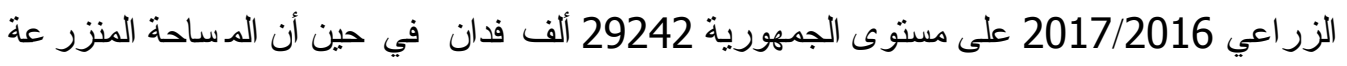

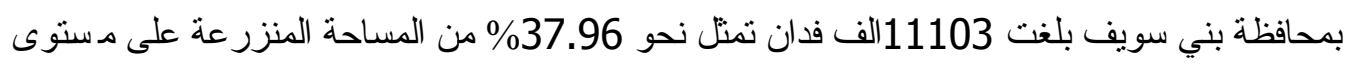

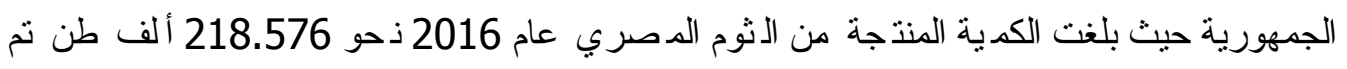

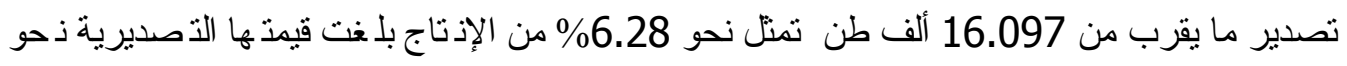

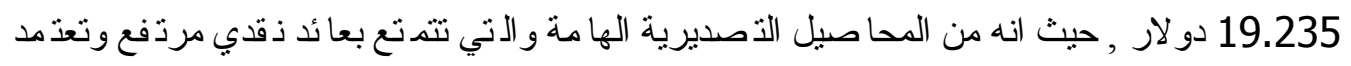
زر اعة الثوم على أسعار السنة السابقة .

\section{مثكلة الدر (سة}

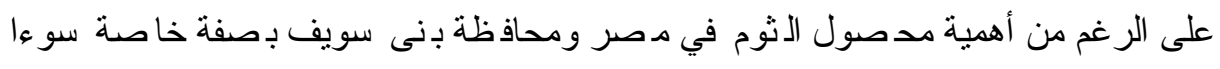

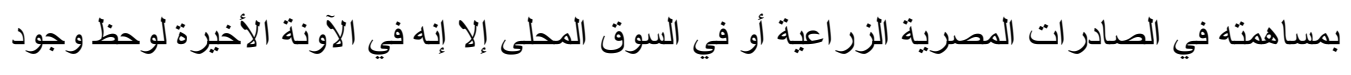

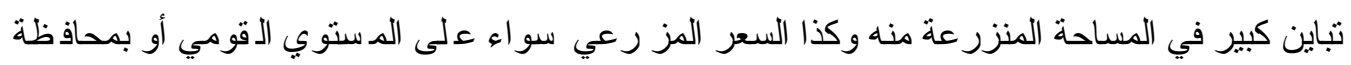


بنى سويف وكذلك وجود تباين بمر اكز المحافظة الأمر الذي أدي إلى تر اجع صادر ات الثوم المصري الثري

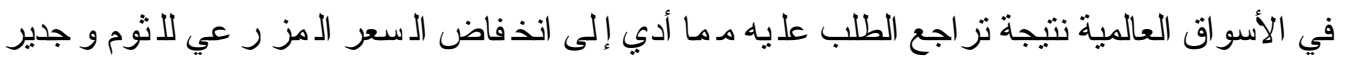

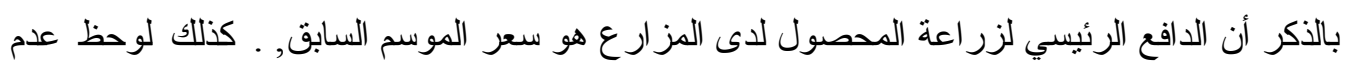

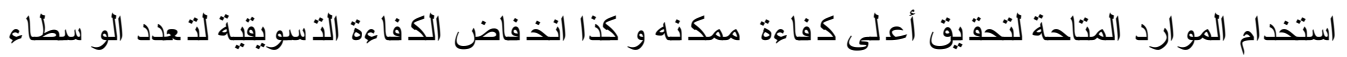

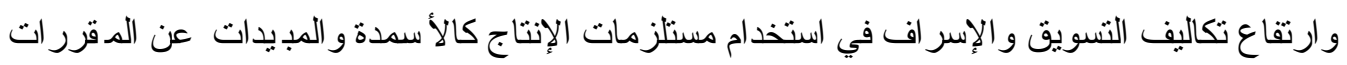

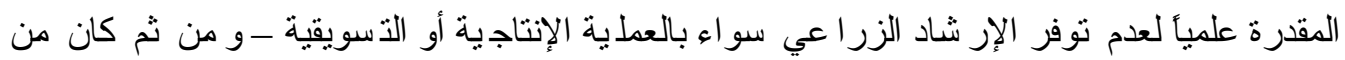

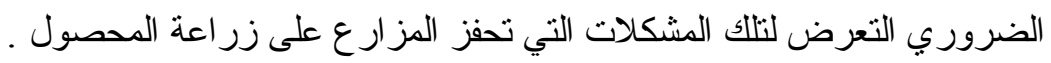

\section{الهذف من الدراسة}

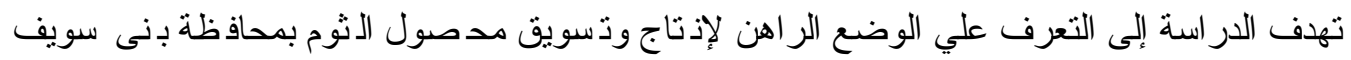

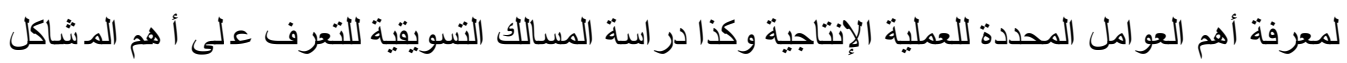
الإنتاجية و التسويقية وذلك من خلال الآتي :

1 2. تحديد العو امل المؤثزة على إنتاج المحصول الإنتاجل لتحديد أعلى عائد ..

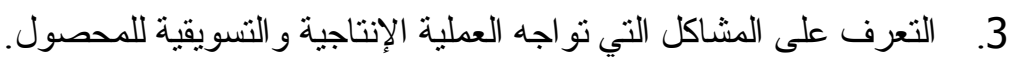

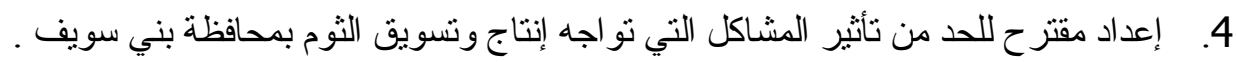
أسلوب الاراسة ومصادر الحصول على البيانات:

نم استخدام الطرق و الأساليب الإحصائية لتحليل البيانات و التي تتفق وطبيات عة البيانيات البات التي تم

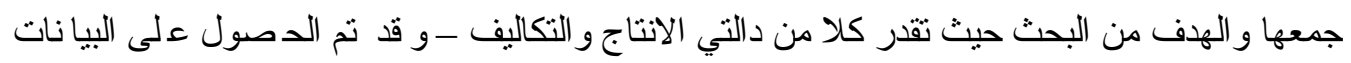

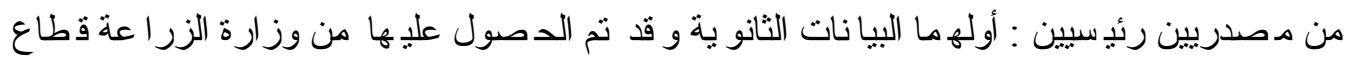

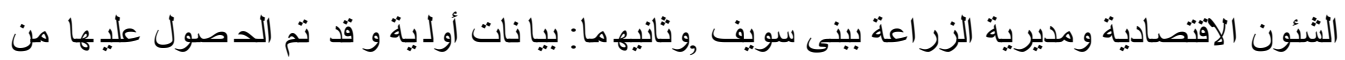
در اسة حالة أجريت بمحافظة بني سويف لمحصول الثوم بالموسم الزر اعي 2017/2016.

\section{اختيار عينة الدر اسة}

لما كان الهحف من الدر اسة التعرف على الوضع الر اهن لمحصول الثوم فكان طبيعيا أن تلاج التهأ

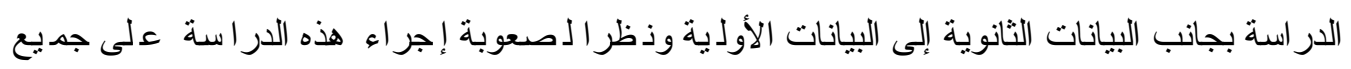

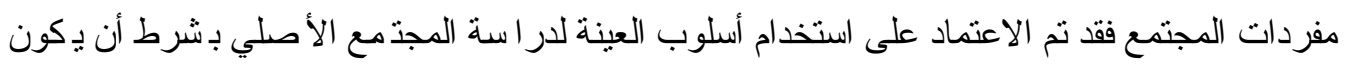

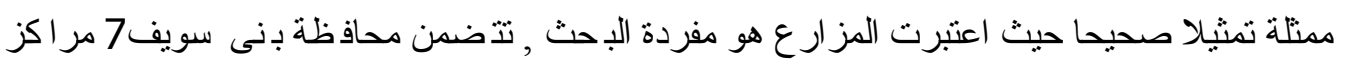

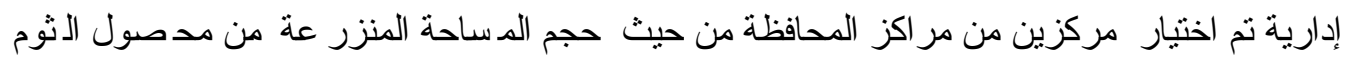

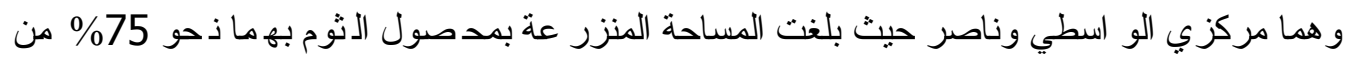

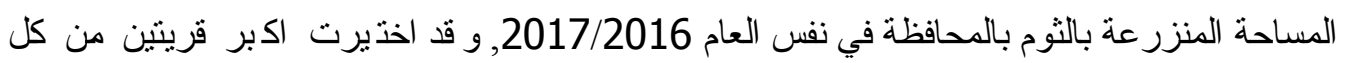

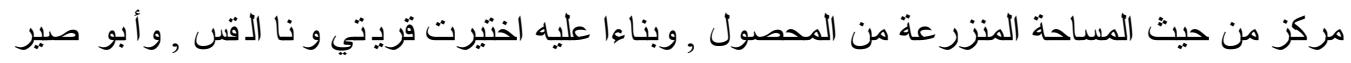

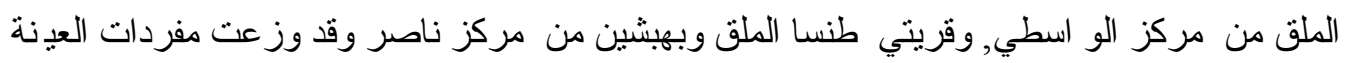

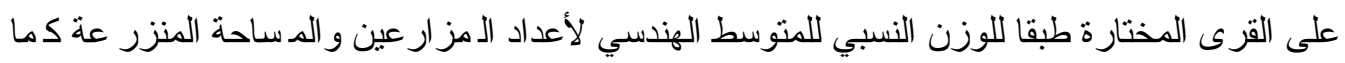

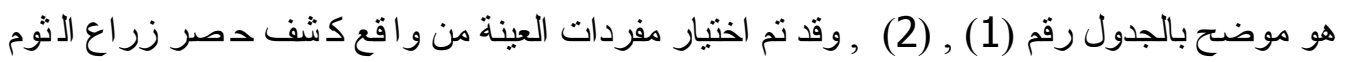

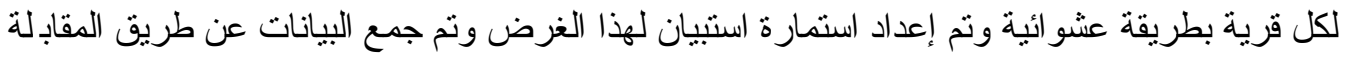


جدول رقم (1) المساحة المنزرعة بمحصول الثوم بمحافظة بنى سويف موسم2017/2016

\begin{tabular}{|c|c|c|}
\hline$\%$ & المساحة (بالفدان) & المركز \\
\hline 52.5 & 5833 & الو اسطى \\
\hline 22.0 & 2447 & ناصر \\
\hline 2.4 & 266 & بنى سويف \\
\hline 19.0 & 2102 & اهناسيا \\
\hline 0.4 & 44 & ببا \\
\hline 3.2 & 359 & سمسطا \\
\hline 05 & 52 & الفتشن \\
\hline 100 & 11103 & الاجمالى \\
\hline
\end{tabular}

المصدر : مديرية الزراعة بينى سويفـ قسم الإحصاء - بياتات غير منثورة .

جدول (2) توزيع مفردات عينة الدراسة لمحصول الثوم على المر اكز والقرى المختارة

بمحافظة بنى سويف 2017/2016

\begin{tabular}{|c|c|c|c|c|c|c|c|}
\hline \multicolumn{3}{|c|}{ القرى المختارة } & \multirow{2}{*}{ المفردات } & \multicolumn{2}{|c|}{ المر اكز المختارة } & \multirow[t]{2}{*}{ المفردات } & \multirow{2}{*}{ المساحة } \\
\hline عدد مفردات & (بالفدان) & القرية & & المساحة (بالفدان) & المركز & & \\
\hline 34 & 1013 & 1- ابو صير الملق & 58 & 5833 & الو اسطي & \multirow{4}{*}{83} & \multirow{4}{*}{ الجملة } \\
\hline 24 & 698 & 2- ونا القس & & & & & \\
\hline 19 & 881 & 1- طنسا الملق & 25 & 2447 & 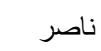 & & \\
\hline 6 & 249 & 2- بهبشين & & & & & \\
\hline 83 & 8280 & الاجمالى & 83 & 8280 & الاجمالى & 83 & 11103 \\
\hline
\end{tabular}

المصدر : مديرية الزراعة بينى سويفـ قسم الإحصاء - بيانات غير منشورة . عرض ومناقشة النتائج

أهم المؤشرات الاقتصادية لمحصول الثوم بجمهورية مصر العربية ومحافظة بني سويف :

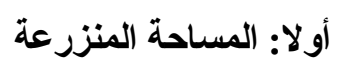

يتبين من الجدول رقم ( 3) أن المساحة المنزرعة بمحصول الثوم بجمهورية مصر العربية قد

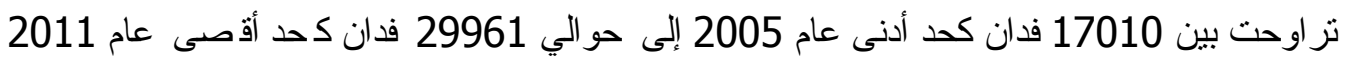
بزيادة قدرت بنحو 12951 فدان يمثل حو الي 52.7\% من المتو سط الـنوي للمساحة و الدقدر بذحو

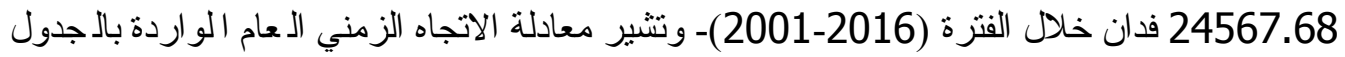

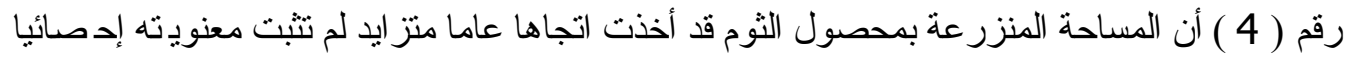

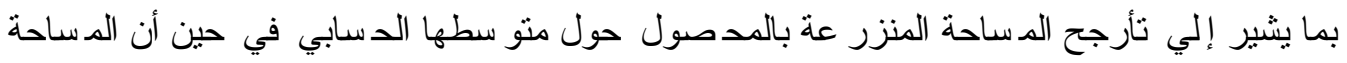
المنزرعة بالحصول بمحافظة بنى سويف نجد أنهانز او حت بين 2989 فدان كحد أدنى عام 2001 ونحو 12810 فدان عام 2015 بزيادة تقدر بنحو 9821 فدان تمثل نحو 114\% من منو سط الد ساحة

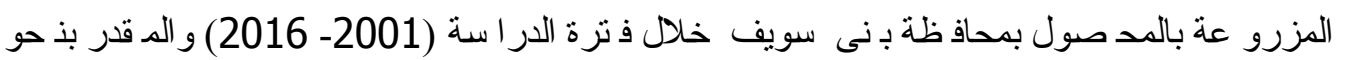

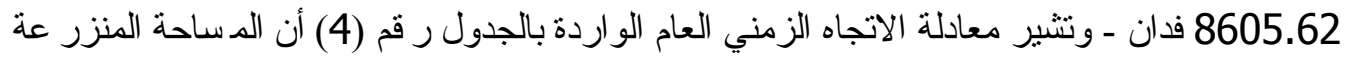

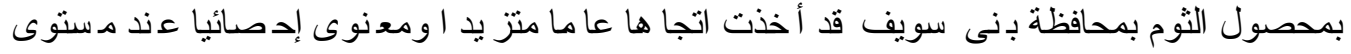


0.01\% وقدر بنحو 1032فدان وبمعدل تغير سنوي 1.88\%. مما سبق بتضح أن المساحة المزرو عة

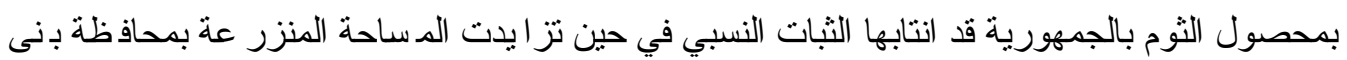

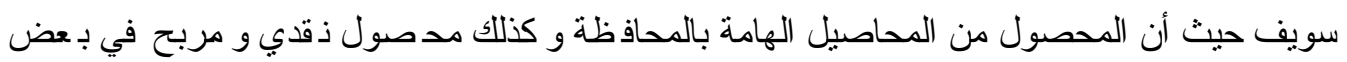

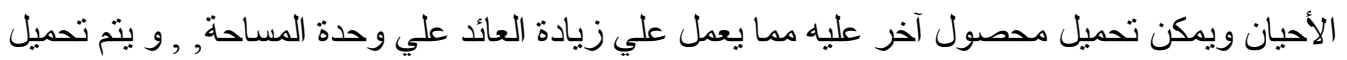

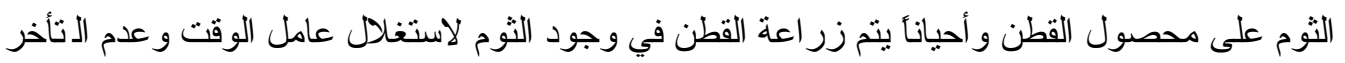

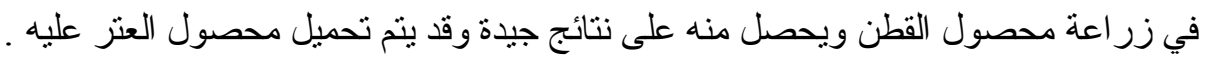
ثانيا: إنتاجية الفدان

ف من بيانات الجدول ر قم ( 3) ذبين أن الإنتاجية الفداذية لمدصول الثوم بجمهور ية مدصر

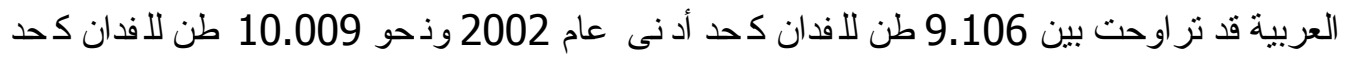
أقصى عام 2009 بزيادة قدرت بذحو 0.903 طن لافدان تمثل ذهو

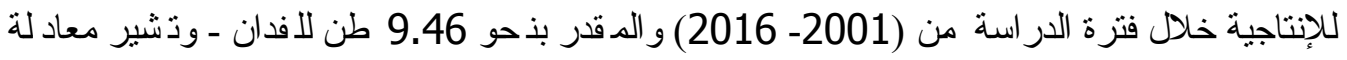

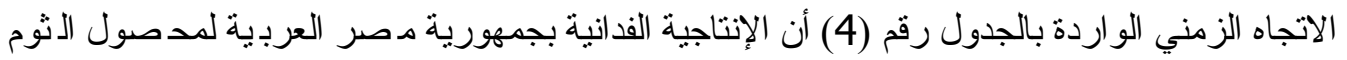

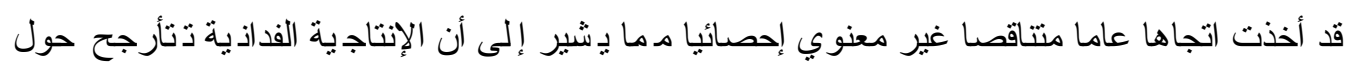

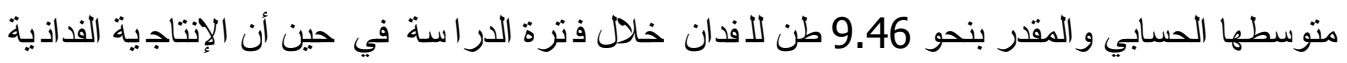
لمحصول الثوم قد نز اوحت بين 10.121 طن للفدان كحد أدنى عام 2016 وبنحو 12 طن للفدان خلال

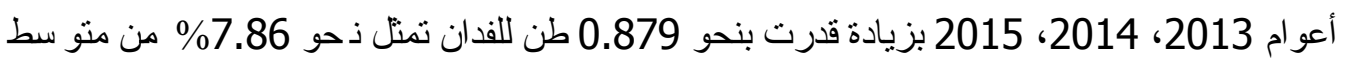

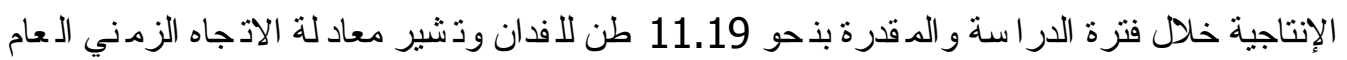

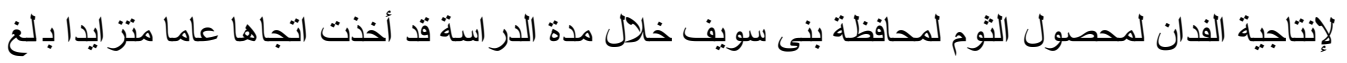

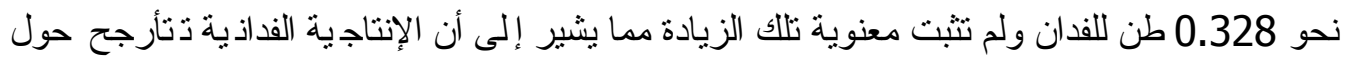
متوسطها الحسابي. مما سبق يتضح أن الزيادة في الإنتاجية الفداذية بمحافظة بنى سويف اكبر من الز يادة على مستوى

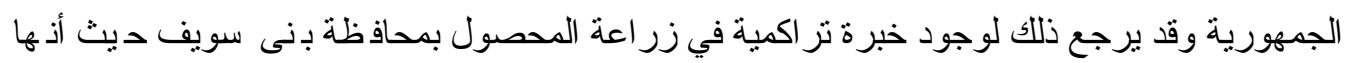
من المحافظات الرئيسية في إنتاج المحصول. 
جدول رقم (3)المؤشر ات الاقتصادية لمحصول الثوم بجمهورية مصر العربية ومحافظة بني سويف خلال الفترة (2016-2001)

\begin{tabular}{|c|c|c|c|c|c|c|c|c|c|c|}
\hline \multicolumn{2}{|c|}{ صني العائد الفداني } & \multicolumn{2}{|c|}{ جنيه/|فدان الفية } & \multicolumn{2}{|c|}{ السعر المزرعي جنيه/طن } & \multicolumn{2}{|c|}{ طن/ للفدانية } & \multicolumn{2}{|c|}{ بالفدان } & \multirow[t]{2}{*}{ السنة } \\
\hline بني سويف & جمهورية & بني سويف & جمهورية & | بني سويف & جمهورية & بني سويف & جمهورية & بني سويف & جمهورية & \\
\hline 1986.0 & 1603.80 & 2130 & 2257.5 & 388 & 388.3 & 10.608 & 9.734 & 2989 & 22130 & 2001 \\
\hline 4453.0 & 3685.50 & 2358 & 2237.0 & 650 & 650.4 & 10.478 & 9.106 & 6407 & 28238 & 2002 \\
\hline 1999.8 & 2015.00 & 2499 & 2370.0 & 489 & 475 & 10.479 & 9.180 & 7239 & 29374 & 2003 \\
\hline 2877.0 & 2218.00 & 2658 & 2688.0 & 500 & 506 & 11.069 & 9.453 & 3186 & 19871 & 2004 \\
\hline 3936.0 & 3399.00 & 2809 & 2850.0 & 600 & 655 & 11.242 & 9.528 & 8901 & 17010 & 2005 \\
\hline 6127.0 & 1668.00 & 4873 & 3077.0 & 1000 & 1031 & 11.000 & 9.490 & 7378 & 17309 & 2006 \\
\hline 3640.0 & 3923.40 & 5960 & 3627.0 & 800 & 1068 & 12.000 & 9.438 & 11291 & 24853 & 2007 \\
\hline 5740.0 & 5453.78 & 5760 & 4759.0 & 1000 & 1109 & 11.500 & 9.209 & 11777 & 28082 & 2008 \\
\hline 8215.0 & 8323.84 & 8285 & 4848.0 & 1500 & 1316 & 11.000 & 10.009 & 5849 & 17450 & 2009 \\
\hline 4300.0 & 21576.51 & 6700 & 5170.0 & 1000 & 2789 & 11.000 & 9.590 & 9998 & 23034 & 2010 \\
\hline 3010.0 & 15360.94 & 6890 & 5665.0 & 900 & 2210 & 11.000 & 9.514 & 11403 & 28916 & 2011 \\
\hline 20890.0 & 8410.44 & 7860 & 5960.0 & 2500 & 1452 & 11.500 & 9.897 & 11017 & 29277 & 2012 \\
\hline 23110.0 & 10144.90 & 6890 & 4793.0 & 2500 & 1515 & 12.000 & 9.860 & 6460 & 22153 & 2013 \\
\hline 1343.0 & 10371.00 & 9457 & 6054.0 & 900 & 1709 & 12.000 & 9.433 & 10060 & 26183 & 2014 \\
\hline 10633.0 & 10316.00 & 7180 & 6122.0 & 900 & 1779 & 12.000 & 9.231 & 12810 & 29961 & 2015 \\
\hline 15965.0 & 15858.00 & 9345 & 8603.0 & 1760 & 2785 & 10.121 & 8.761 & 10925 & 29242 & 2016 \\
\hline 7389.05 & 7770.51 & 5728.4 & 4442.53 & 1086.68 & 1339.86 & 11.19 & 9.46 & 8605.62 & 24567.68 & المنوسط \\
\hline
\end{tabular}

المصدر:ثوزارة الزراعة واستصلاح الأراضي- قطاع الثئون الاقتصادية ـ نشرة الاقتصاد الزراعي أعداد مختلفة. 
جدول رقم (4) بعض المؤشر ات الاقتصادية لمحصول الثوم بجمهورية مصر العربية ومحافظة بنى سويف خلا الفترة (2016-2001)

\begin{tabular}{|c|c|c|c|c|c|c|c|}
\hline المعدل التغير & السندي التغير & المتوسط & 2 & ن & معادلة الاتجاه الزمني العام & البيان & المتغير التابع \\
\hline 1.2 & 300 & 24567.68 & 0.127 & 2.035 & 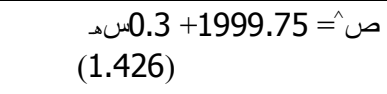 & الجمهورية & \multirow[t]{2}{*}{ بالفدان المة المنزرعة } \\
\hline 1.88 & 1023 & 8605.62 & 0.437 & $* * 10.871$ & 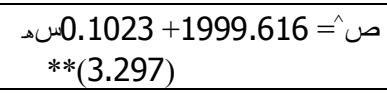 & بنى سويف & \\
\hline 8.6 & 0.821 & 9.46 & 0.003 & 0.044 & $\begin{array}{l}\text { صن = =0.821-2016.274 } \\
(0.209-)\end{array}$ & الجمهورية & \multirow[t]{2}{*}{ طان/الفانية الفدانية } \\
\hline 2.9 & 0.328 & 11.19 & 0.208 & 3.682 & 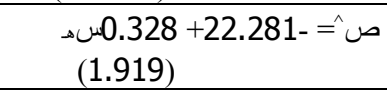 & بنى سويف & \\
\hline 3.1 & 500 & 1339.86 & 0.676 & $* * 29.210$ & 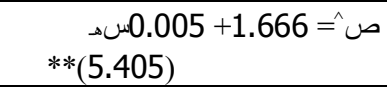 & الجمهورية & \multirow[t]{2}{*}{ جنيد/طن الأسعار المزرعية } \\
\hline 9.0 & 470 & 1086.68 & 0.600 & $* * 20.988$ & 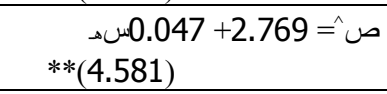 & بنى سويف & \\
\hline 4.5 & 200 & 4442.53 & 0.888 & **111.305 & 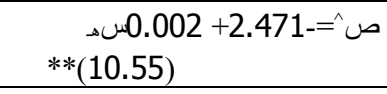 & الجمهورية & \multirow[t]{2}{*}{ جنيد/فان الفانيف الفدانية } \\
\hline 1.75 & 100 & 5728.4 & 0.901 & $* * 128.470$ & 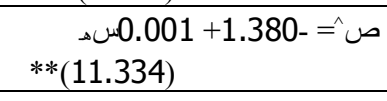 & بنى سويف & \\
\hline 6.43 & 50 & 7770.51 & 0.539 & $* * 16.399$ & $\begin{array}{l}\text { صu0.00005 +3.922 = ص } \\
* *(4.050)\end{array}$ & الجمهورية & \multirow[t]{2}{*}{ جنيه/فيدان العائد الفدانى } \\
\hline 5.4 & 40 & 7389.05 & 0.368 & $* 8.143$ & 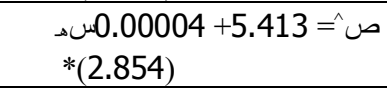 & بنى سويف & \\
\hline
\end{tabular}

(3) المصدر حسبت من بياتات الجدول رقم

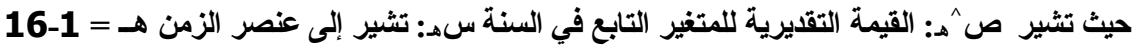

هـ*معنوي عند مستوى معنوية 0.05**معنوي عند مستوى معنوية 0.001 
ثالثاً :الأسعار المز رعية تتبير بيانات الجدول رقم (3) أن السعر المزرعى للطن من مدصول الثوم بجمهور ية مدصر العربية قد نر اوح بين 388.3 جنيه/ طن عام 2001 كحد أدنى ونحو 2785 جنيه/طن كحد أقصى سنى عام

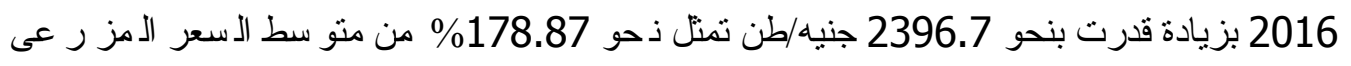

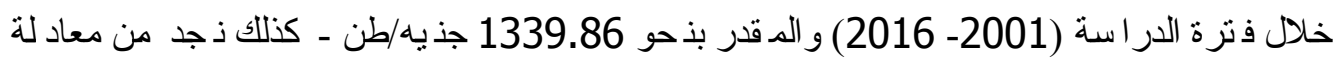
الاتجاه الزمني العام للسعر المزرعي للطن من محصول الثوم بجمهورية مصر العربية أنه قد اخذ اتجا ها

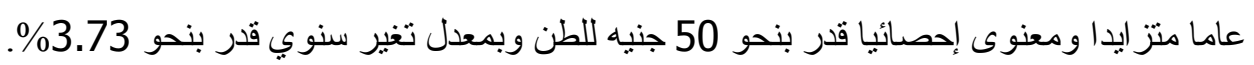

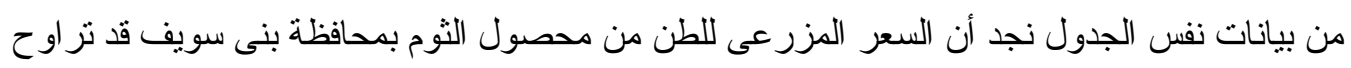

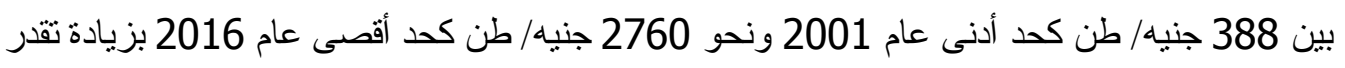

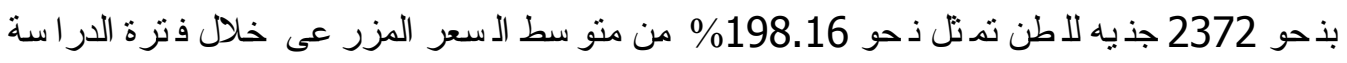

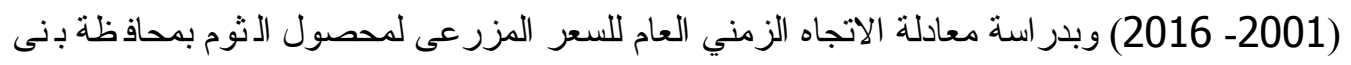

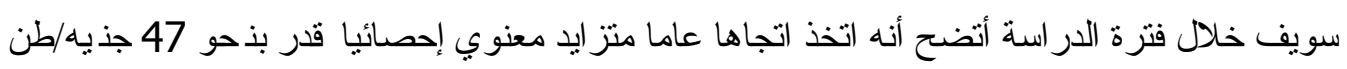
وبمعدل تغير سنوي 4.32\% رابعا: التكاليف الفدانية تشير بيانات الجدول رقم ( 3 ) أن التكاليف الفدانية لمحصول الثوم بجمهور ية دصر العربة بية

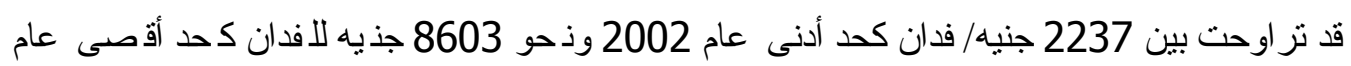

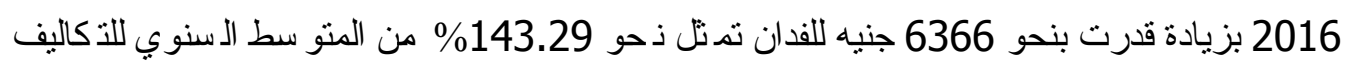

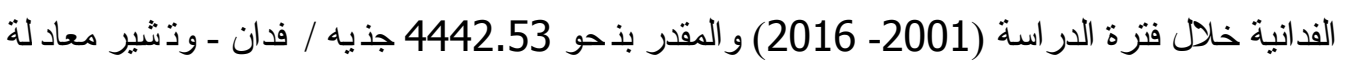

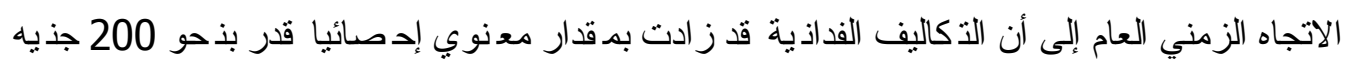

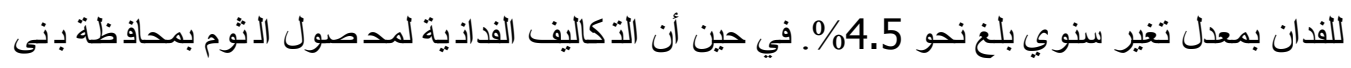

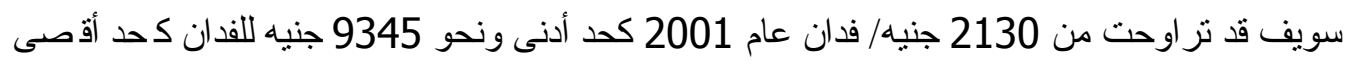

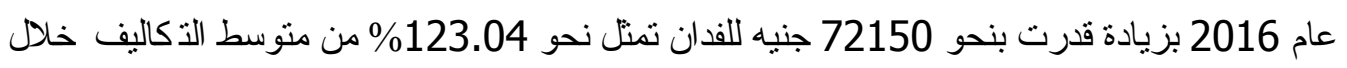

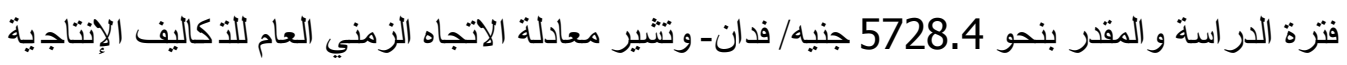

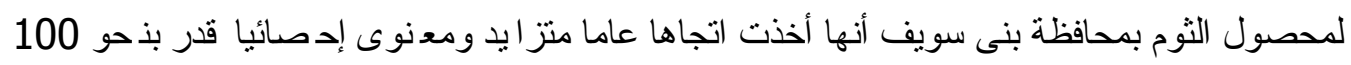
جنيه/ فدان وبمعدل تغير سنوي بلغ نحو 1.75\%

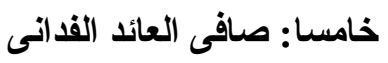
تشير بيانات الجدول رقم (3) أن صافى العائد الفدانى من مدصول الفئل الثوم بجمهور ية دصر

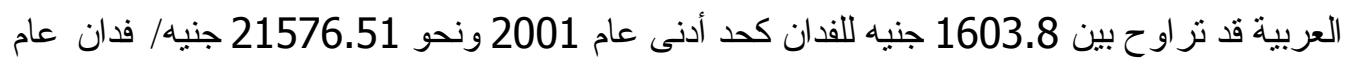

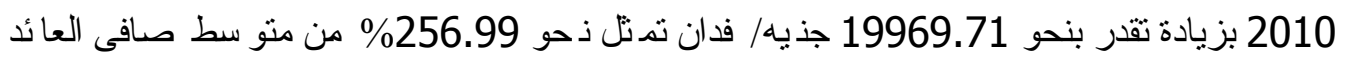

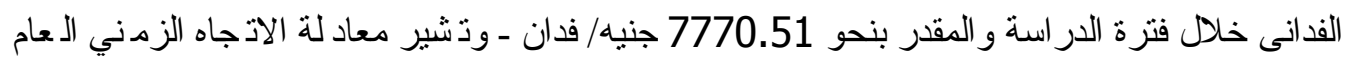

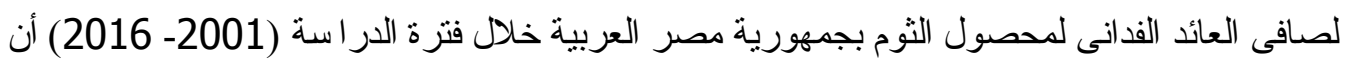

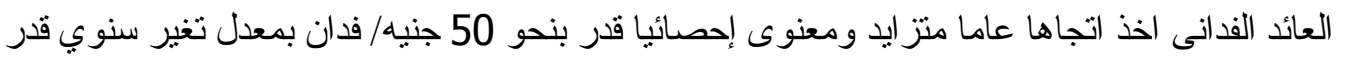

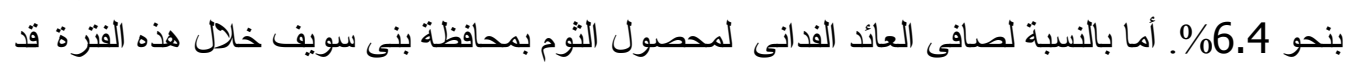

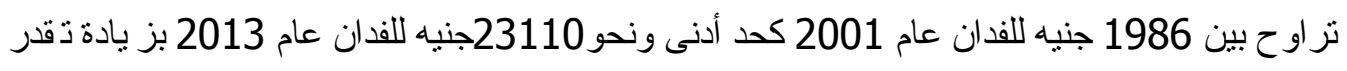
بنحو 21124 جنيه للفدان تمثل نحو 279.67\% من منوسط العائد السنوي خلال فترة الدر اسة و المقدر

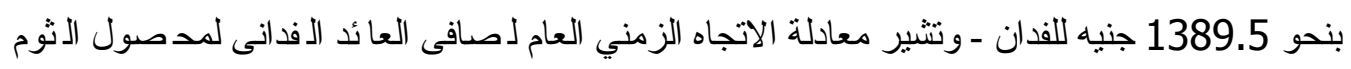


بمحافظة بنى سويف خلال فترة الدر اسة أنه اتخذ أيضا اتجاها عاما متز ايد ومعنوى إدصائبا قدر بذحو 40 جنيه للفدان بمعدل تغير سنوي 5.4\%

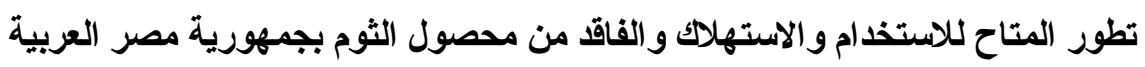

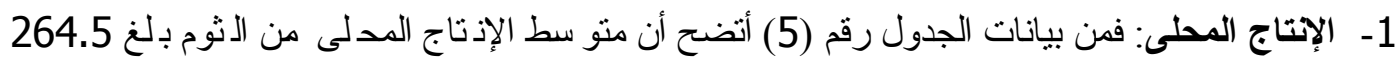

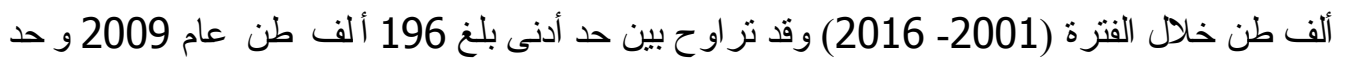

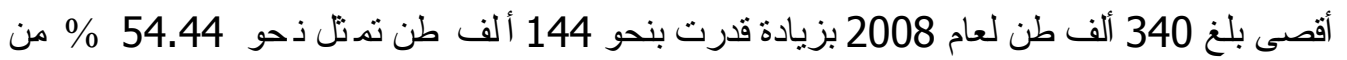

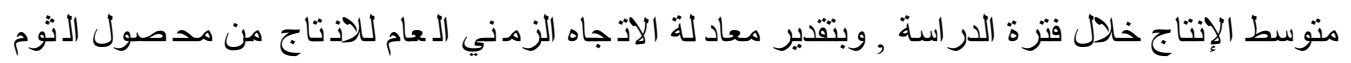

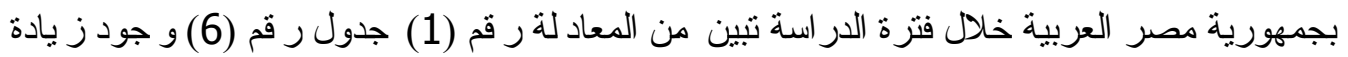
سنوية غير معنوية إحصائيا قدرت بنحو 1.994الف طن - مما يثير إلى تأرجح الإنتاج حول منو سطه

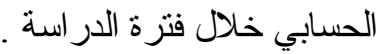

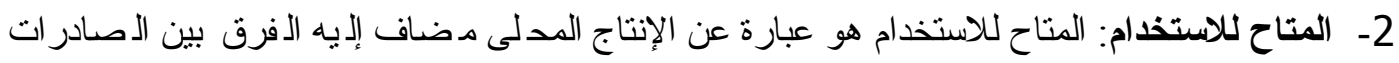

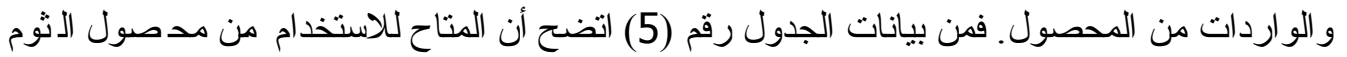

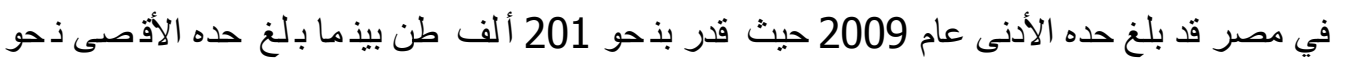

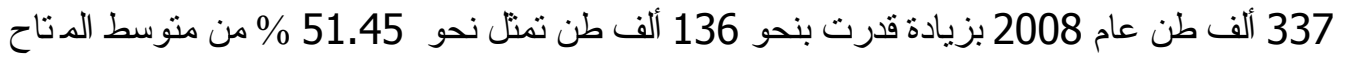
للاستخدام خلال فترة الدر اسة المقدر بنحو 264.311 ألف طن - وبدر اسة الاتجاه الزمني الإمام للمناح

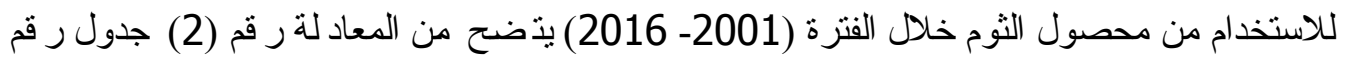

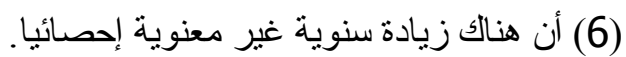

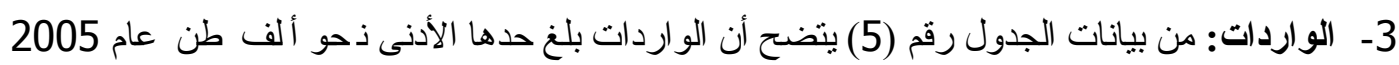

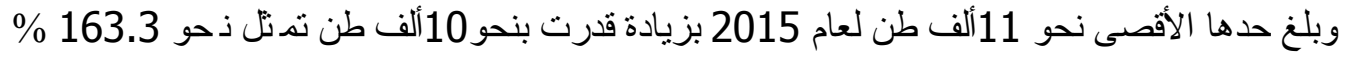

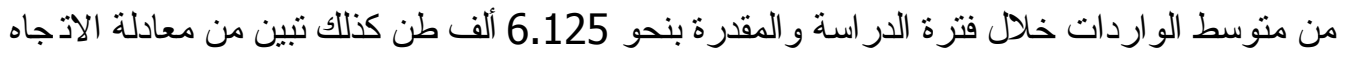

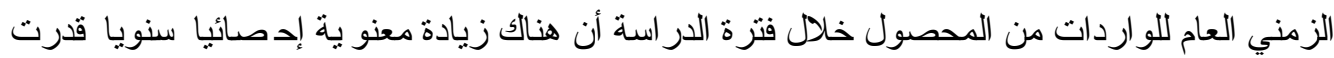
بنحو 1.036 ألف طن وبمعدل نمو سنوي بلغ 16.9 \% جدول رقم (5) بعض المؤشرات الاقتصادية لمحصول الثوم في مصر

خلال الفترة من (2001-20016)

\begin{tabular}{|c|c|c|c|c|c|c|c|}
\hline نصبيّ/ الفقرد & بالألف طن & بالألفت طن & بالألف طنادن & بالألف طن & بالألف طن & بالألإنتاجة & السنة \\
\hline 3.37 & 14 & 218 & 2 & 4 & 232 & 230 & 2001 \\
\hline 3.55 & 14 & 234 & 4 & 6 & 248 & 246 & 2002 \\
\hline 3.64 & 14 & 245 & 10 & 3 & 259 & 266 & 2003 \\
\hline 3.74 & 15 & 257 & 5 & 2 & 272 & 275 & 2004 \\
\hline 3.11 & 18 & 218 & 7 & 1 & 236 & 242 & 2005 \\
\hline 2.68 & 14 & 191 & 5 & 3 & 215 & 217 & 2006 \\
\hline 3.78 & 23 & 276 & 4 & 4 & 309 & 309 & 2007 \\
\hline 3.83 & 52 & 285 & 6 & 3 & 337 & 340 & 2008 \\
\hline 2.23 & 41 & 170 & 3 & 8 & 201 & 196 & 2009 \\
\hline 2.74 & 40 & 213 & 4 & 12 & 253 & 245 & 2010 \\
\hline 3.06 & 45 & 244 & 15 & 8 & 289 & 296 & 2011 \\
\hline 2.94 & 63 & 240 & 13 & 7 & 303 & 309 & 2012 \\
\hline 2.22 & 49 & 186 & 7 & 8 & 235 & 234 & 2013 \\
\hline 2.62 & 59 & 225 & 28 & 7 & 284 & 263 & 2014 \\
\hline 2.83 & 46 & 249 & 7 & 11 & 295 & 291 & 2015 \\
\hline 2.44 & 41 & 220 & 23 & 11 & 261 & 273 & 2016 \\
\hline 3.049 & 34.25 & 229.438 & 8.938 & 6.125 & 264.313 & 264.5 & الهتوسط \\
\hline
\end{tabular}

المصدر : الجهاز المركزي للتعيئة العامة والاحصاء ــنشرات الامن الغذائي أعداد مختلفة . 
4ـ الصادرات: اتضح أن الصادرات من محصول الثوم بلغت حدها الأدنى نحو 2ألف طن عام 2001 وحدها الأقصى نحو 28 ألف طن عام 2014 بزيادة قدرت بنحو 26 ألف طن تمنتل ذنحو 290.9

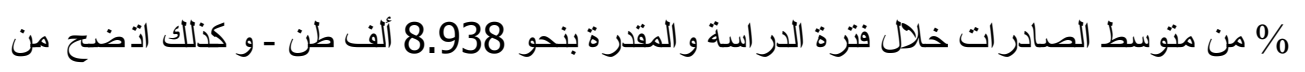

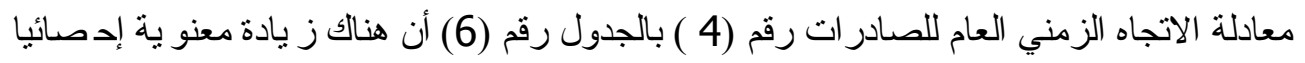

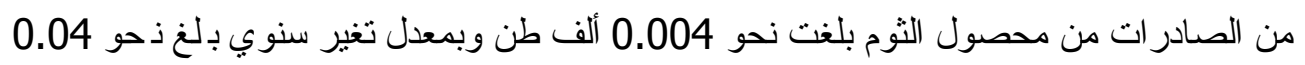
$\%$ 5- الاستهلاك: يتضح من بيانات الجدول رقم (5) أن الاستهلاك من مدصول الثوم تأرجح بين حدي

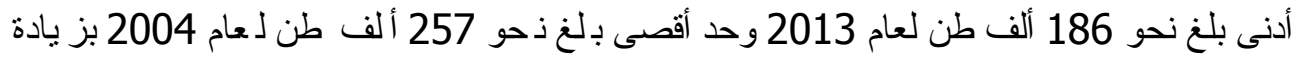

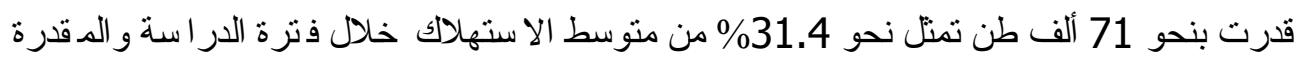

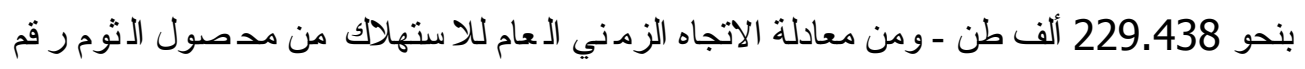

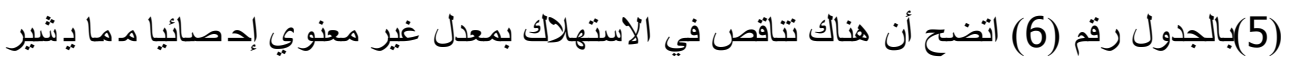

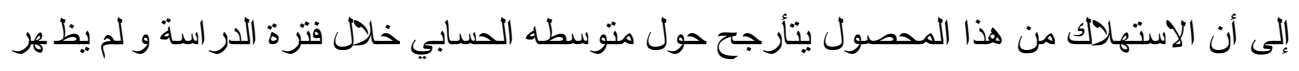

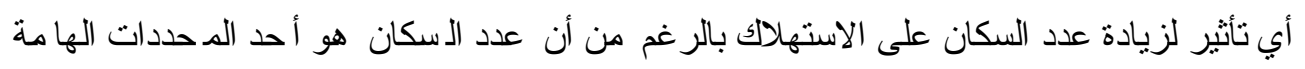

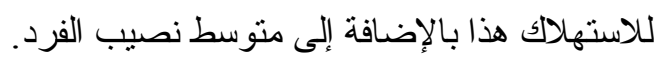

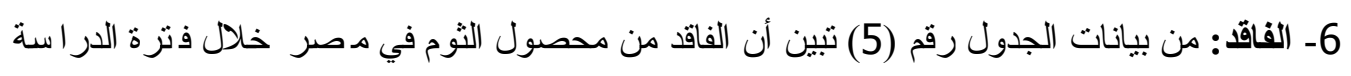
تر اوح بين حد أدنى بلغ نحو 14 ألف طن خلال أ عو ام

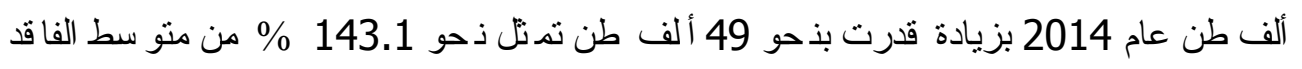

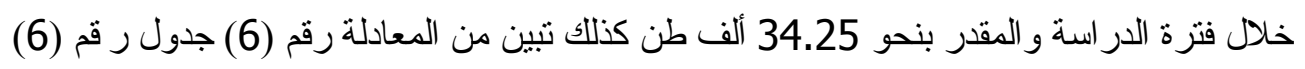

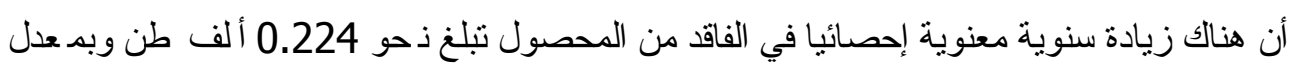

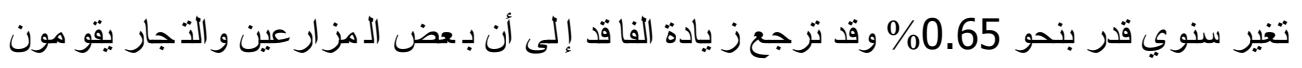

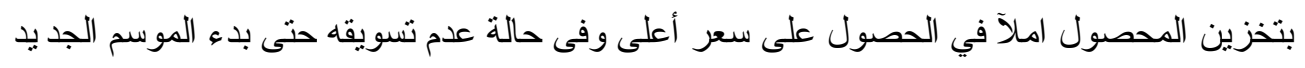

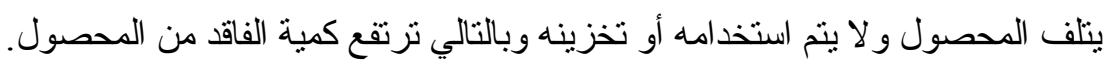

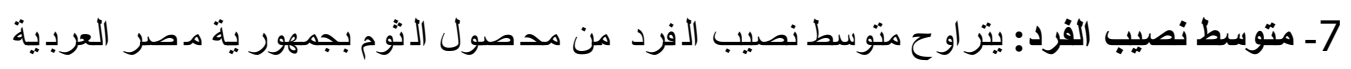

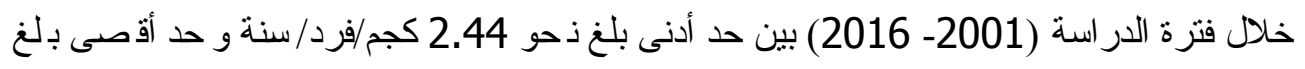

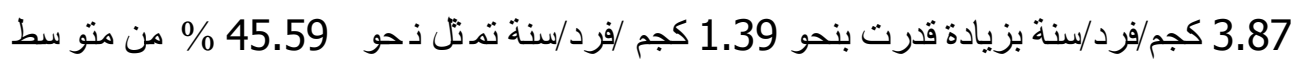

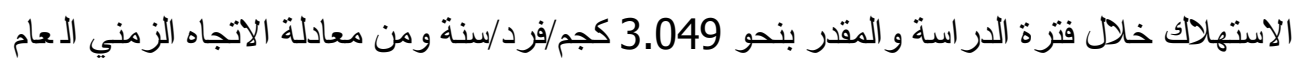

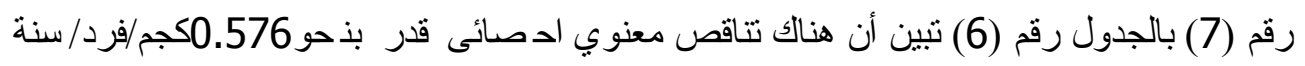
وبمعدل تغير سنوي بلغ نحو 18.9\%من منوسط نصيب الفرد السنوي. 
جدول (6) بعض المؤشرات الاقتصادية لمحصول الثوم بجمهورية مصر العربية

خلا الفترة (2001- 2016)

\begin{tabular}{|c|c|c|c|c|c|c|c|}
\hline \% اللتنغير & مقدار الثغبر & المتوسط & 2, & ن ن & معادلة الاتجاه الزمني العام & رقم & المتغير التابع \\
\hline 0.75 & 1.994 & 264.5 & 0.062 & 0.924 & $\begin{array}{l}\text { ص^ه = } 1.994 \text { سهـ } 247.55 \text { سـ } \\
0.961)\end{array}$ & 1 & الانتاج بالالف طن \\
\hline 0.014 & 0.037 & 264.323 & 0.084 & 1.280 & $\begin{array}{l}\text { ص^^ـ= - 1.389+ } 0.037 \text { سـه } \\
\text { (1.132) }\end{array}$ & 2 & المتاح بالالف طن \\
\hline 16.9 & 1.036 & 6.125 & 0.55 & $* * 17.413$ & $\begin{array}{l}\text { ص^د = 1.036 +2.157 } \\
* *(4.173)\end{array}$ & 3 & طالو اردات بالالف \\
\hline 0.04 & 0.004 & 8.938 & 0.388 & *8.877 & $\begin{array}{l}\text { ص^A = 4.921+ } 0.004 \text { سـ } \\
* 2.979)\end{array}$ & 4 & طن \\
\hline 0.007 & 0.17 & 229.438 & 0.114 & 0.194 & $\begin{array}{l}\text { ص^د = 12.6- } 0.017 \text { سد } \\
(0.44-)\end{array}$ & 5 & طن \\
\hline 0.65 & 0.224 & 34.25 & 0.703 & $* * 33.214$ & $\begin{array}{l}\text { ص^^ـ= } 0.224+0.815 \text { سهـ } \\
* * \text { * } 5.763)\end{array}$ & 6 & الفاقت بالالف طن \\
\hline 18.9 & 5.760 & 3.044 & 0.401 & $* * 11.103$ & 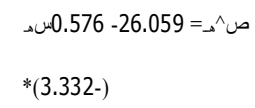 & 7 & متوسط الفربي \\
\hline
\end{tabular}

المصدر: جمعت وحسبث من بيانات الجدول رقم (5)

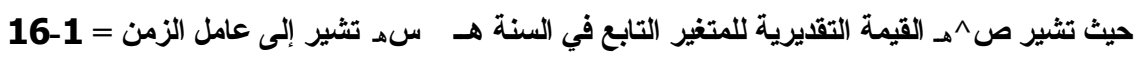

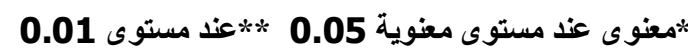

تقدير دالة تكاليف إنتاج محصول الثوم على مستوى العينة

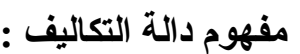

تعرف التكاليف بأنها اجمالى المبالغ المدفوعة و المقدرة التي تتحمل ها المذشاة في سبيل إذتاج كمية معينة من المنتج , ويقصد بدالة التكاليف الإتتاجية تلك العلاقة المقدرة بين ماتتحمدله المذشاة في

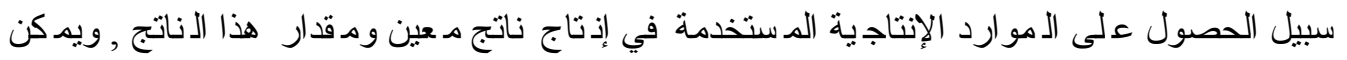
الاستفادة من دو ال التكاليف الإنتاجية المقدرة في الحصول على بعض المشتقات الاقتصادية التي تقيد في

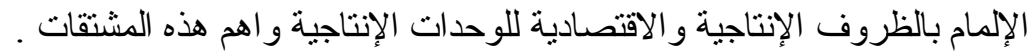

متوسط التكاليف الكلية :

يقصد بمنوسط التكاليف الكلية ما يخص الوحدة المنتجة من التكاليف الكلية ويمكن الحصول عليها بقسمة التكاليف الكلية على كمية الإنتاج . متوسط التكاليف المتغيرة :

يقصد بمتوسط التكاليف المتغيرة ما يخص الوحدة المنتجة من التكاليف المتغيرة ,ويمكن الحصول عليها بقسمة التكاليف الإنتاجية المتغيرة على كمية الإنتاج . 


\section{التكاليف الحدية :}

و هى عبارة عن معدل التغير في التكاليف الكلية لزيادة الناتج الكلى بمقدار وحدة تغير واحدة

ويمكن التعبير عنها رياضياً عن طريق المشتقة الأولى لدالة التكاليف الكلية .

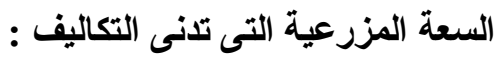

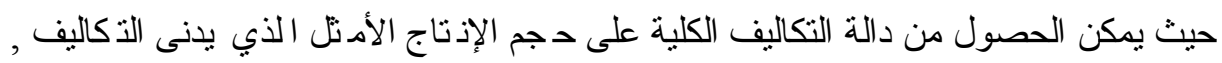

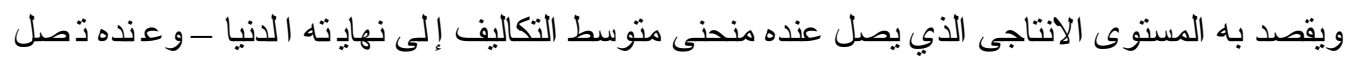

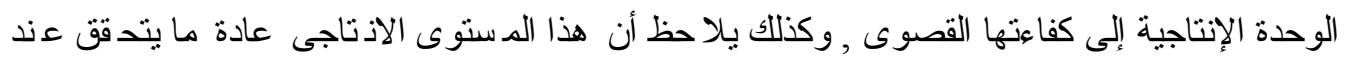

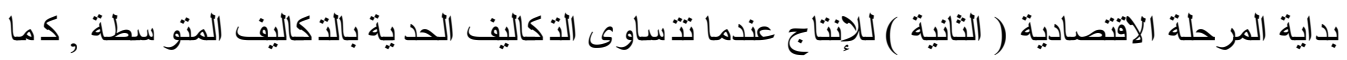

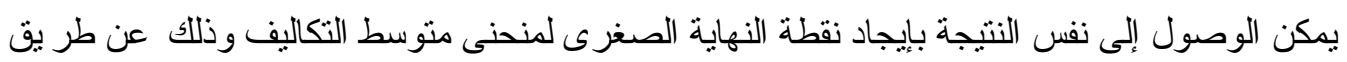

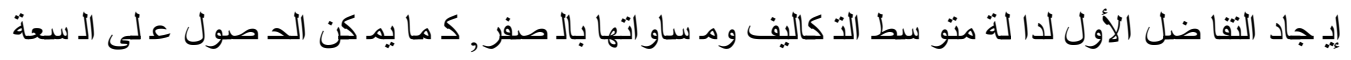
المزرعية التي تدنى التكاليف عن طريق خار ج القسمة التالي : حجم الإنتاج الأمثل الأى يانىى التكاليف

السعة المز رعية التي تعظم الربح :

حيث يمكن الحصول من دالة التكاليف الكلية على الحجم الإنتاج الأمتل الذي يعظم الربح الربح عن

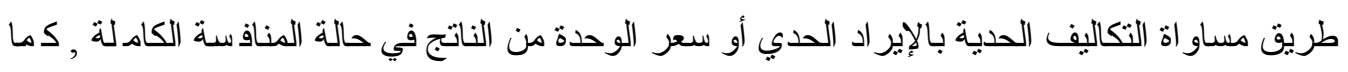

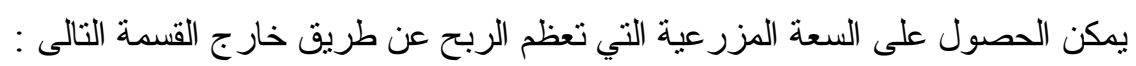

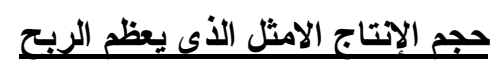
متوسط انتاج القدان

وبالنظر إلى التقدير الإحصائي لدالة التكاليف الكلية و التي هي علاقة بين التغير في ذكاليف الاناتج تابع

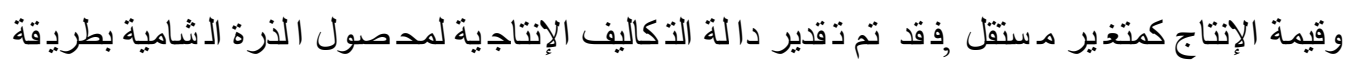

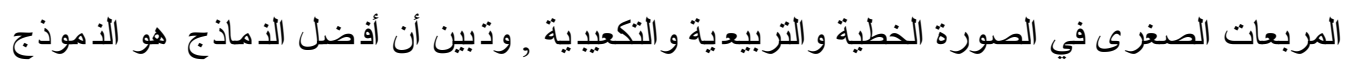

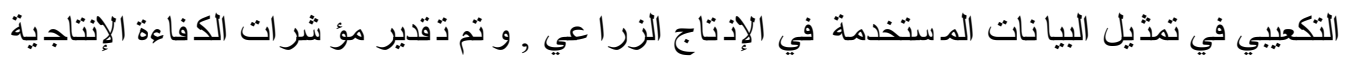

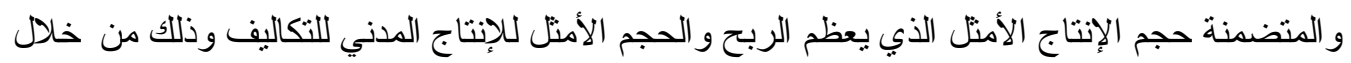
دالة التكاليف التالية :

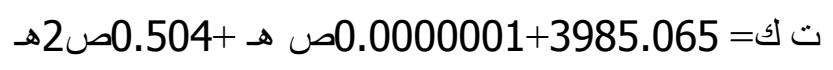

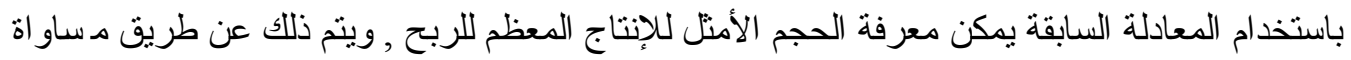

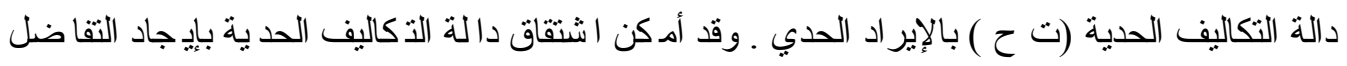

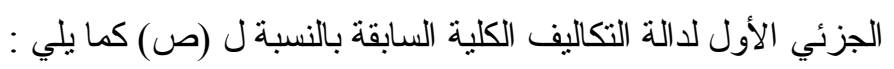
ت ح = ص=11.07 و ومساو اة المعادلة (1) بالإير اد الحدي و هو سعر الطن بالجنيه فيكون الحجم الأمثل للإنتاج المعظم للربح هو 11.07 طن للفدان . مأ. وقد أمكن الحصول علي ادني نقطة علي منحني متوسط التكاليف الكلية عن طريق مساو اة دالة التكاليف الحدية سالفة الذكر مع دالة متوسط التكاليف الكلية حيث أمكن الحصول علي دالة منوسط التكاليف الكلية من قسمة التكاليف علي حجم الإنتاج . 
ص=8.342.طن للفدان وقد اتضح من مساو اة الداليتين أن حجم الإنتاج عند أدني نقطة علي مندني دالة التكاليف ( الحجم المحقق لأقل تكلفة إنتاجية منو سطة ) قد بـلغ 8.342 طن لافدان , وبحساب مرو نة

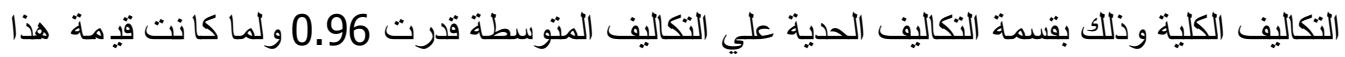
المعامل أقل من الواحد الصحيح فإن ذلك يؤكد أن إنتاج محصول الثوم بمحافظة يتم في المرحلة التولة الأو لي

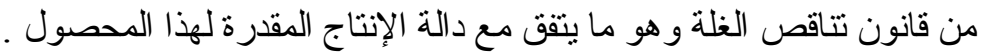
تطور تكاليف الاتتاج لمحصول الثوم بجمهورية مصر العربية ومحافظة بني سويف :

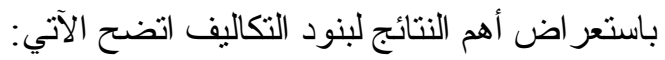
أولا : تكلفة العمل البشري :فمن بيانات الجداول أرقام (7),(8) يتضح أن متوسط تكلفة العمل البشري

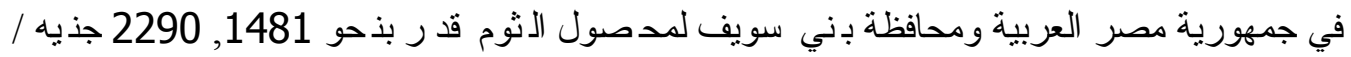
فدان تمنل نحو 29.4\% , 26\% من منو سط إج مالي التكاليف الكاية لمدصول الثوم و المقدرة بذحو

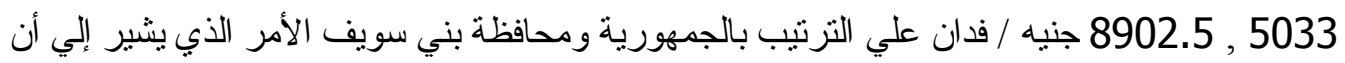

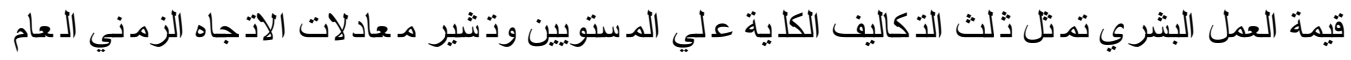

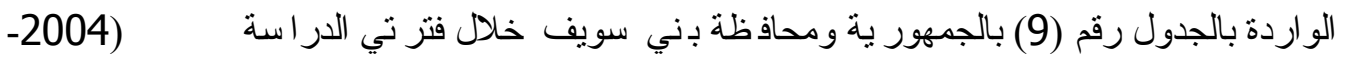

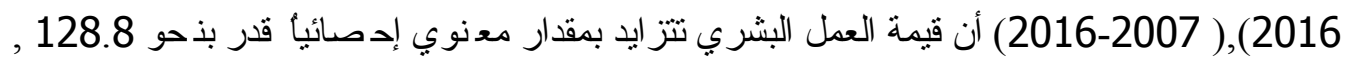

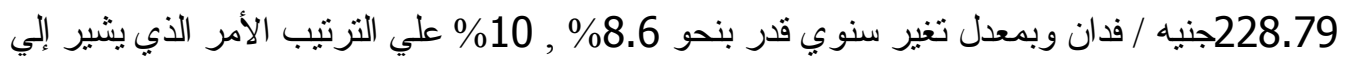

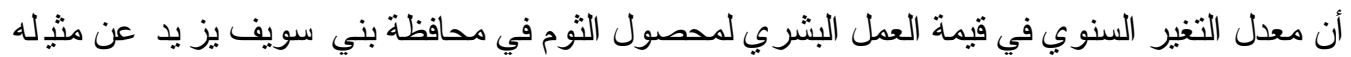

بالجمهورية وقد يعزي ذللك لارتفاع أجر العامل الزر اعي بالمحافظة عن مثيله بالجمهورية .

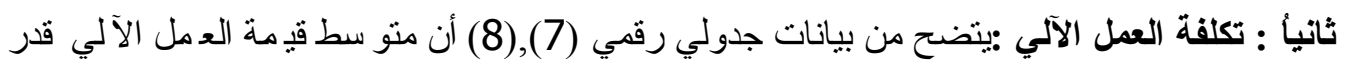

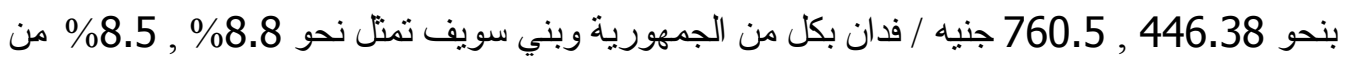

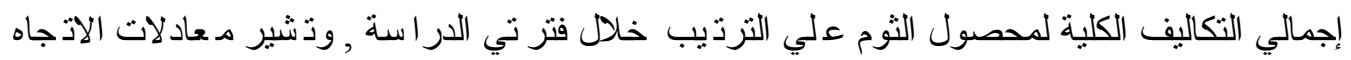

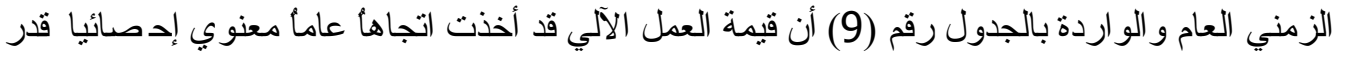

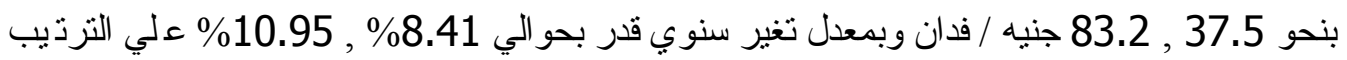

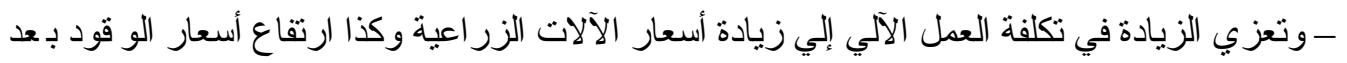
رفع جزء من الدعم عليه , وكذا ارتفاعقيمة الصيانة اللازمة لتشغيل الآلات .

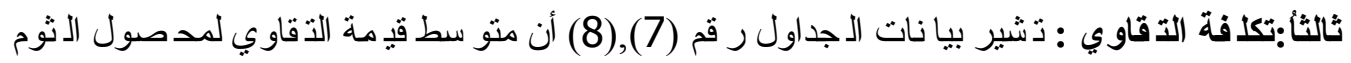

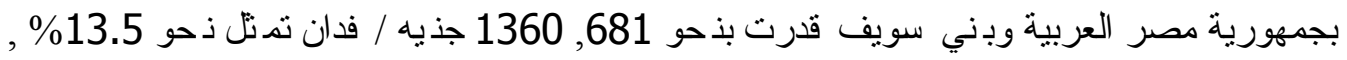

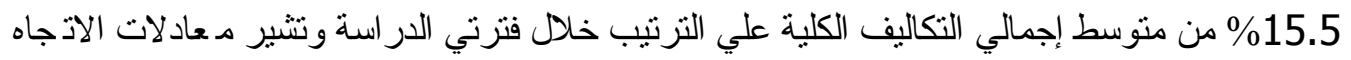
الزمني العام الو اردة بالجدول رقم (9) أن قيمة التقاو

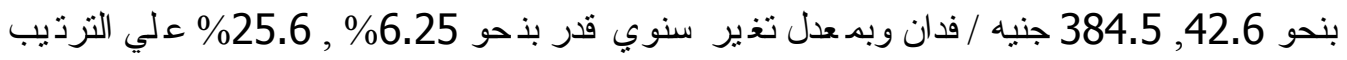

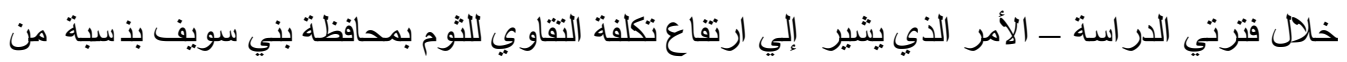

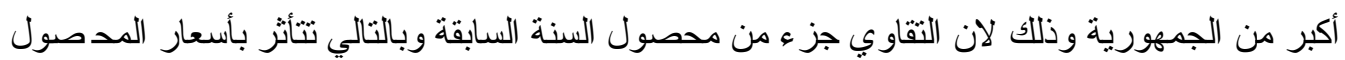

في السنة السابقة والذي غالباً ما يكون بينهما اختلاف بين الجمهورية وبني سويف ـ الفيان

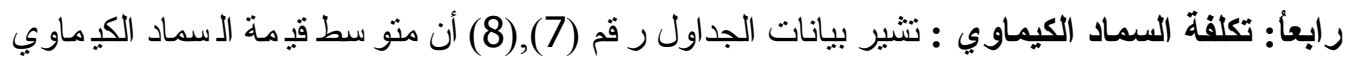
لمحصول الثوم بجمهورية مصر العربية وبني سويف قدرت بذحو 85 .1138.1,555جنيه / فدان 
تمنت نحو 11\%,\%من متوسط إجمالي التكاليف الكلية لمحصول الثوم في جمهور ية مصر العربية

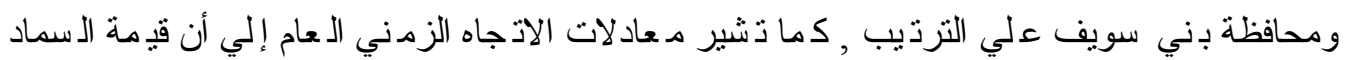

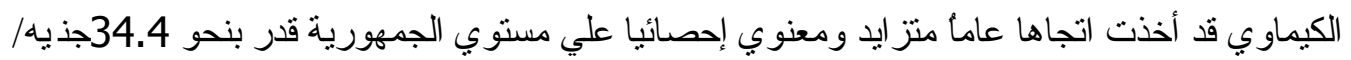

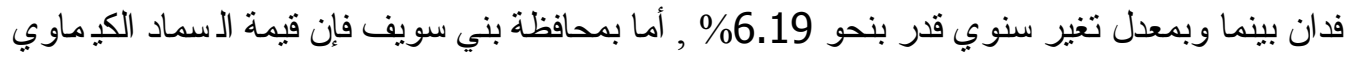

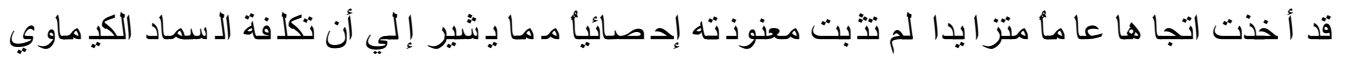

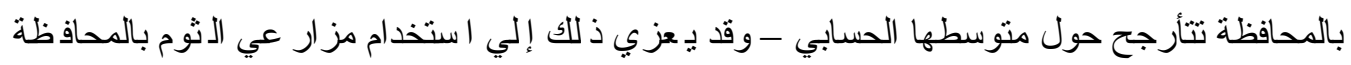

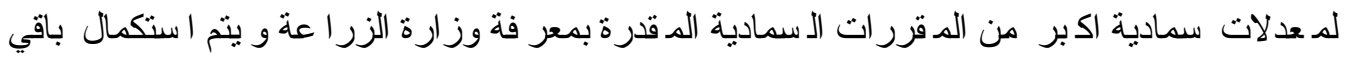

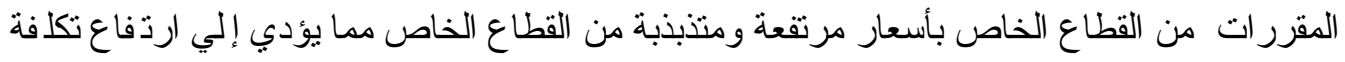

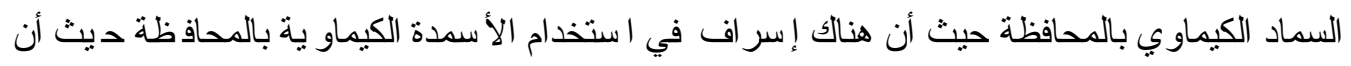

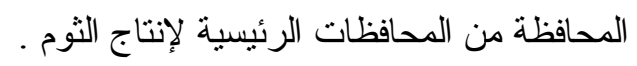

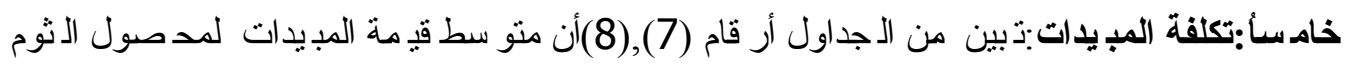

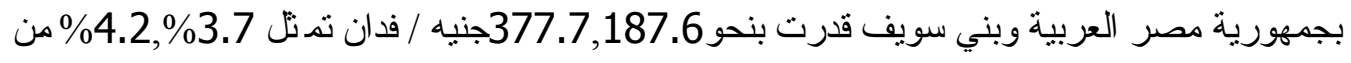

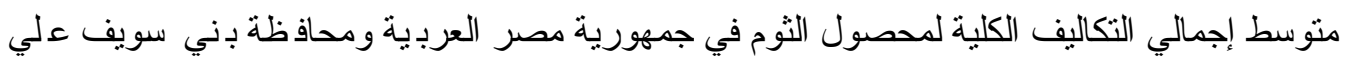

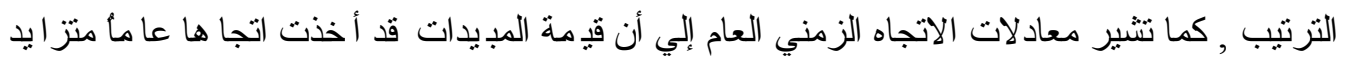

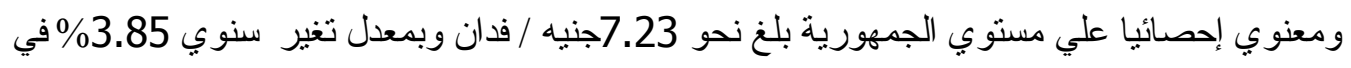

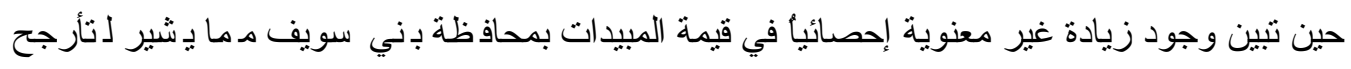

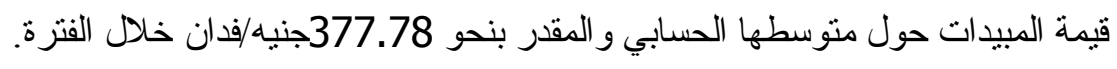
جدول رقم (7) تكاليف العمليات الزراعية لمحصول الثوم بجمهورية مصر العربية

\begin{tabular}{|c|c|c|c|c|c|c|c|c|c|c|}
\hline \multicolumn{3}{|c|}{ (جنيه/فدان) } & \multicolumn{5}{|c|}{ خلا الفترة من (2016-2004) } & & & \\
\hline التكاليف & الإيجار & التناليفة & عصومية & مبيدات & كميمة & قبمة & التقاوي & آلاتو & ألعمال & السنة \\
\hline 2688 & 673 & 2015 & 200 & 164 & 284 & 37 & 427 & 243 & 660 & 2004 \\
\hline 2850 & 720 & 2130 & 211 & 164 & 327 & 34 & 466 & 262 & 665 & 2005 \\
\hline 3077 & 731 & 2346 & 233 & 154 & 329 & 42 & 518 & 278 & 791 & 2006 \\
\hline 3627 & 818 & 2809 & 279 & 178 & 389 & 115 & 536 & 306 & 1006 & 2007 \\
\hline 4759 & 985 & 3774 & 374 & 191 & 643 & 137 & 623 & 383 & 1422 & 2008 \\
\hline 4848 & 1082 & 3766 & 373 & 132 & 651 & 106 & 577 & 428 & 1498 & 2009 \\
\hline 5170 & 1088 & 4082 & 405 & 181 & 564 & 126 & 786 & 460 & 1559 & 2010 \\
\hline 5665 & 1632 & 4433 & 418 & 163 & 718 & 131 & 719 & 493 & 1790 & 2011 \\
\hline 5960 & 1208 & 4752 & 460 & 192 & 676 & 156 & 730 & 468 & 2069 & 2012 \\
\hline 4793 & 1105 & 4688 & 465 & 204 & 664 & 150 & 726 & 553 & 1925 & 2013 \\
\hline 6054 & 1105 & 4949 & 490 & 227 & 647 & 172 & 881 & 613 & 1918 & 2014 \\
\hline 7337 & 1215 & 6122 & 486 & 218 & 631 & 220 & 980 & 613 & 1830 & 2015 \\
\hline 8603 & 3108 & 5495 & 545 & 271 & 703 & 255 & 896 & 703 & 2121 & 2016 \\
\hline 5033.15 & 1190.00 & 3950.85 & 379.92 & 187.62 & 555.85 & 129.31 & 681.92 & 446.38 & 1481.08 & المتوسط \\
\hline
\end{tabular}

المصدر :*وزارة الزراعة واستصلاح الأراضيـ قطاع الثئون الاقتصادية ـ نشرة الاقتصاد الزراعي أعداد مختلفة. * باية السلسلة الزمنية بالجدول طبقا للبيانات المتاحة. 
جدول رقم (8) تكاليف العمليات الزراعية لمحصول الثوم في محافظة بني سويف (جنيه/فدان) خلا الفترة (2007-2016)

\begin{tabular}{|c|c|c|c|c|c|c|c|c|c|c|}
\hline التكاليفية & الإيجار & التكاليفة & عصدمية & مبيديةت & قيماو سماد & قبماد & قالثقاوية & آلأن & ألجاز & السنة \\
\hline 4851 & 2400 & 2451 & 100 & 300 & 396 & 200 & 200 & 290 & 965 & 2007 \\
\hline 5960 & 1400 & 45 & 100 & & 1360 & 250 & 800 & 470 & 1580 & 2008 \\
\hline 5760 & 2400 & 3360 & 100 & 150 & 960 & 200 & 400 & 520 & 1300 & 2009 \\
\hline 8285 & 2000 & 6285 & 200 & 350 & 775 & - & 1500 & 910 & 2550 & 2010 \\
\hline 6700 & 2000 & 4700 & 100 & 300 & 675 & 200 & 600 & 780 & 2045 & 2011 \\
\hline 6890 & 2000 & & 100 & 300 & 665 & 200 & 350 & 760 & 2525 & 2012 \\
\hline 7860 & 3000 & 4860 & 100 & 300 & 645 & 200 & 350 & 740 & 2525 & 2013 \\
\hline 12110 & 4000 & 8110 & 150 & 300 & 655 & 400 & 3000 & 940 & 2665 & 2014 \\
\hline 9349 & 3000 & & 629 & 350 & 750 & 300 & 1000 & 845 & 2475 & 2015 \\
\hline 21260 & & & 3 & 1050 & 4500 & - & 5400 & 1350 & 3660 & 2016 \\
\hline 8902.50 & 2720.00 & 6182.50 & 187.90 & 377.78 & 1138.10 & 243.75 & 1360.0 & 760.5 & 2290.0 & المتوسط \\
\hline
\end{tabular}

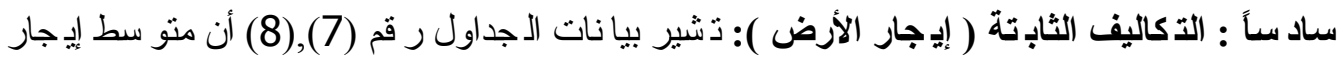

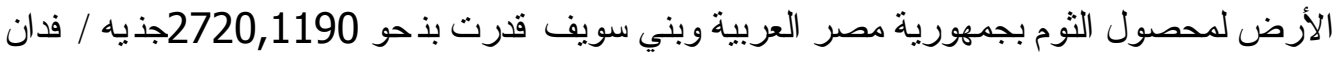

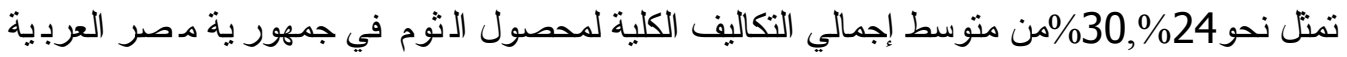

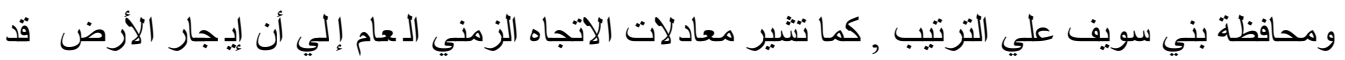

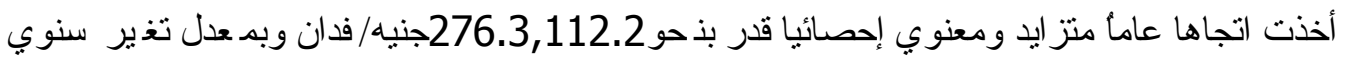

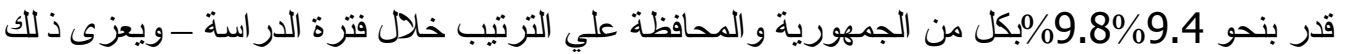

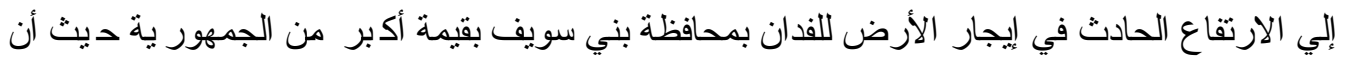

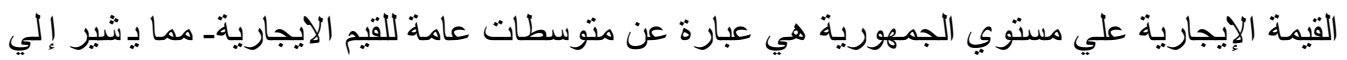
أن التكاليف الثابتة والمتمنلة في القيمة الإيجار ية تمثل ذسبة ذنر اوح من 25-30\% من إج مالي قي مة التكاليف الكلية لأغلب المحاصيل الزر اعية. جدول رقم (9) معدلات الاتجاه الزمني العام لأهم بنود التكاليف الإنتاجية

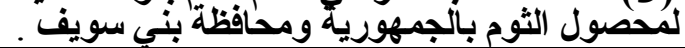

\begin{tabular}{|c|c|c|c|c|c|c|c|}
\hline السنو التغير \% معن & 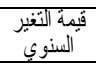 & المنّوسط & $2 \jmath$ & ف & المعادلــــــــــــة & البيان & المتغير \\
\hline 8.69 & 128.802 & 1481.08 & 0.88 & ${ }^{* *} 84.549$ & 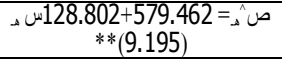 & جمهورية & \multirow{2}{*}{ قألبشر العمل } \\
\hline 10.26 & 228.788 & 2229.0 & 0.760 & $* 29.425$ & 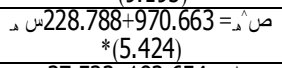 & بني سويف & \\
\hline 8.41 & 37.533 & 446.38 & .974 & ${ }^{* *} 405.363$ & 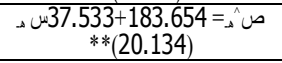 & جمهورية & \multirow{2}{*}{ العمل الآلي } \\
\hline 10.95 & 83.242 & 760.50 & .739 & **22.645 & 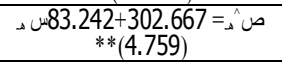 & بني سويف & \\
\hline 6.25 & 42.648 & 681.92 & .907 & ${ }^{* *} 107.137$ & 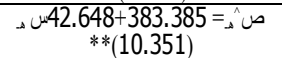 & جمهورية & \multirow{2}{*}{ قيمة التقاوي } \\
\hline 25.62 & 348.485 & 1360 & .411 & $* 5.589$ & 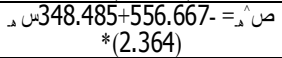 & بني سويف & \\
\hline 6.19 & 34.418 & 555.85 & .695 & ${ }^{* *} 25.034$ & 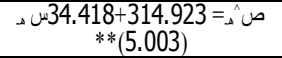 & جمهورية & \multirow{2}{*}{ نكلفة السماد } \\
\hline 16.37 & 186.309 & 1138.1 & .218 & 2.231 & 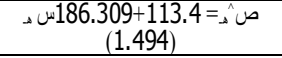 & بني سويف & \\
\hline 3.85 & 7.225 & 187.62 & .601 & ${ }^{* *} 16.574$ & 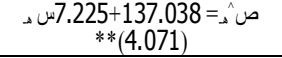 & جمهورية & \multirow[t]{2}{*}{ قيمة المبيدات } \\
\hline 13.75 & 51.935 & 377.78 & .347 & 3.719 & 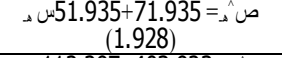 & بني سويف & \\
\hline 9.44 & 112.297 & 1190.00 & .479 & ${ }^{* *} 10.116$ & 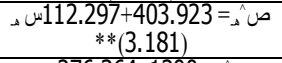 & جمهورية & \multirow{2}{*}{ قيمة الإيجار } \\
\hline 9.83 & 276.364 & 2720.00 & .600 & ${ }^{* *} 12.017$ & 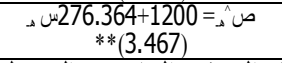 & بني سويف & \\
\hline
\end{tabular}


التقدير الإحصائي للاوال الأتتاجية( الفيزيقية) لمحصول الثوم من عينة الارسة: من خلال البيانات التي أمكن الحصول عليها من استمارة الاستبيان أمكن تقدير العلاقات الدالية الية بين كمية الإنة

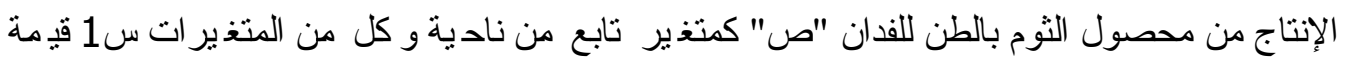

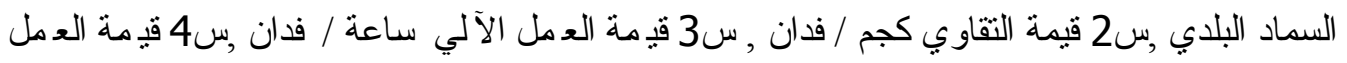

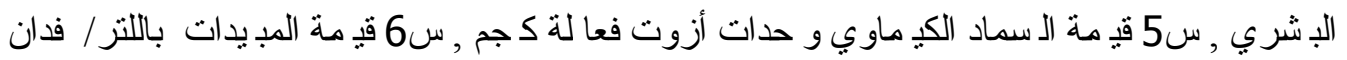

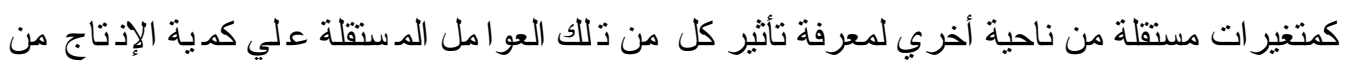

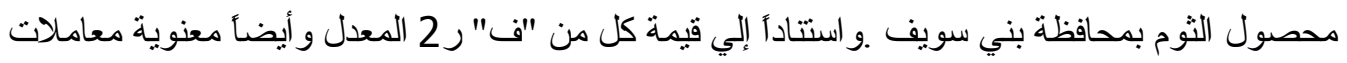

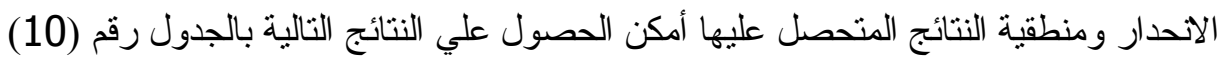

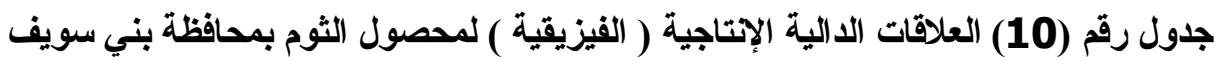

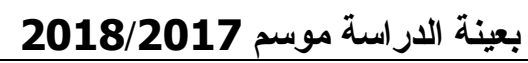

\begin{tabular}{|c|c|c|c|c|}
\hline ن & المرونة - الإجمالية & $2-3$ & الدالة & النووذج \\
\hline \multirow{2}{*}{52.603} & \multirow{2}{*}{0.686} & \multirow{2}{*}{0.806} & 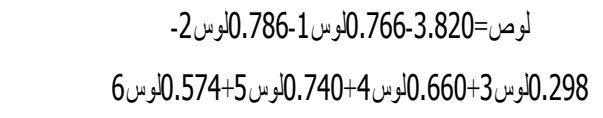 & \multirow{2}{*}{ اللوغ غاريتد } \\
\hline & & & $\begin{array}{cc}* *(6.980) & (2.730) \\
& (2.101-) \quad(2.105-)(1.999-) \\
& *(3.790)\end{array}$ & \\
\hline
\end{tabular}

المصدر: حسبت من بيانات إستمارة الإستبيان الخاصة بعينة الاراسة موسم 2018/2017

$$
\text { القيمة بين الأقواس تثير إلي قيمة ت المحسوبة }
$$

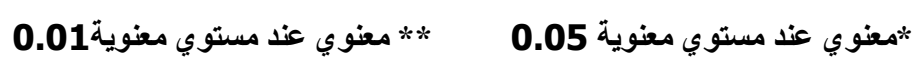
حيث ص=الكمية المقدرة لانتاجية الفدان من محصول الثوم بالطن. س2= كمية التقاوي (كجم /قدان) . س1=السماد البلاي (م3/فان) س4=4العمل البشري(رجل/يوم/عمل/فـان) س3= العمل الآلي (ساعة / فدان)

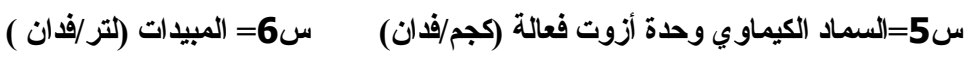

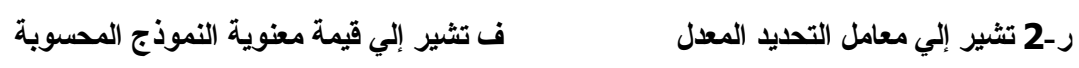
وقد أوضحت النتائج المتحصل عليها من خلال هذا النموذج أن هنالك علا قة موجبة فئة (معنو ية إدصائياً)

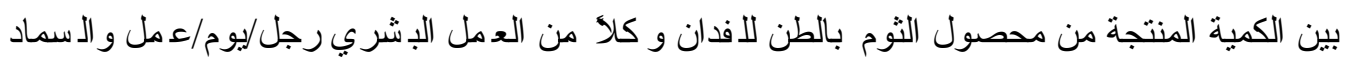

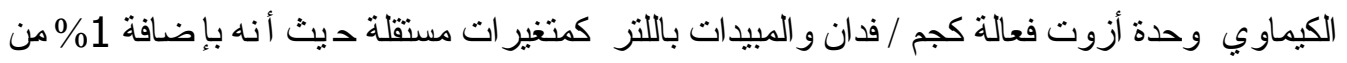

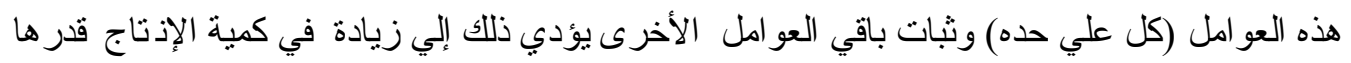

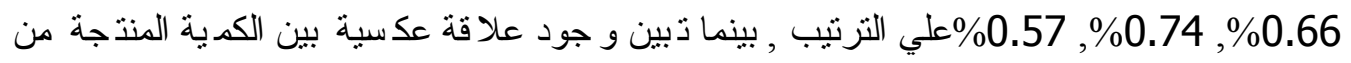

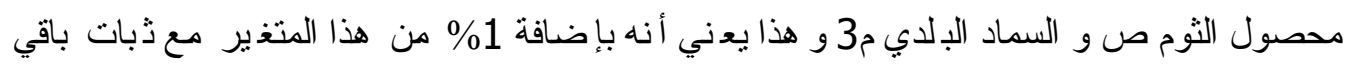

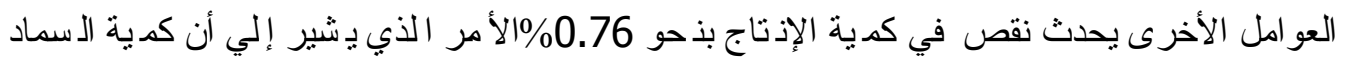

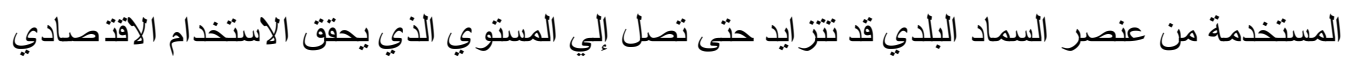

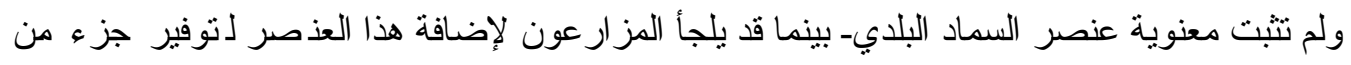

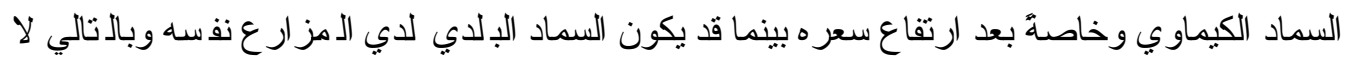

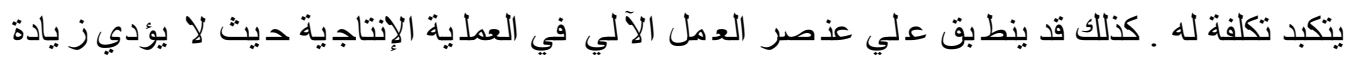

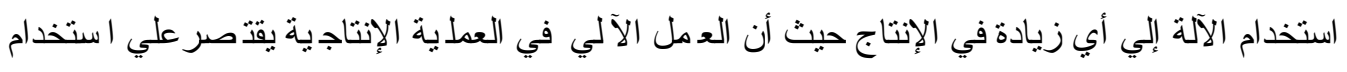

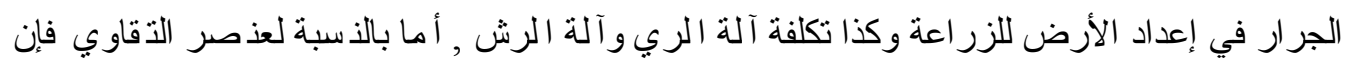


معدل التقاوي يتز اوح بين حدي أدني و أعلي 240-300كجم للفدان و أن أب ز يادة في دمعدل التقاوي لا

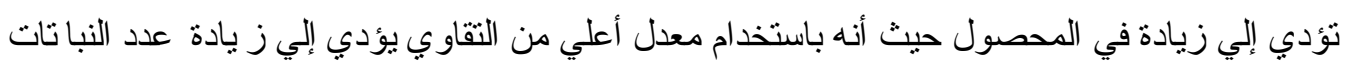

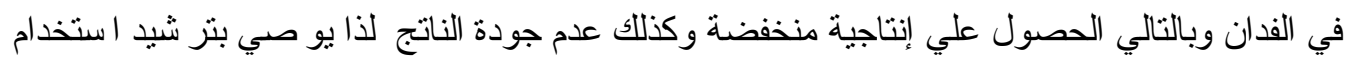

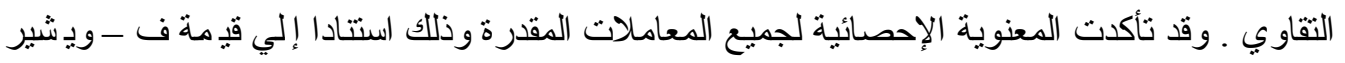

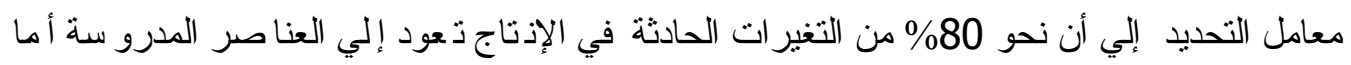

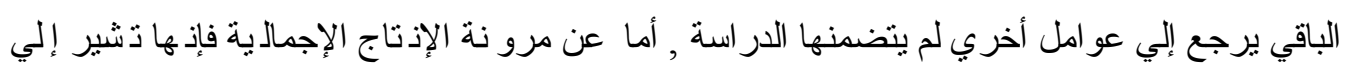

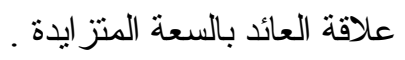
أهم المؤشرات الاتتصادية للاورات الزرالئة بالمية بمحافظة بني سويف :

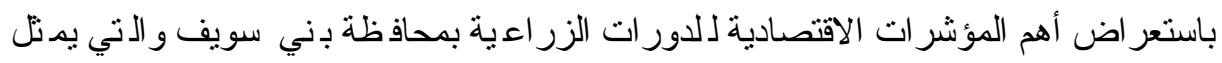

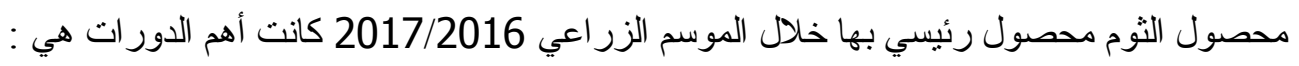

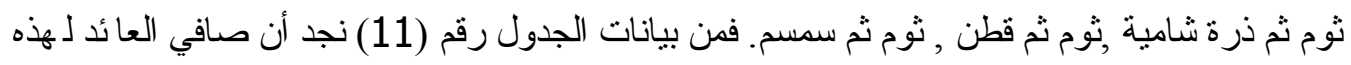

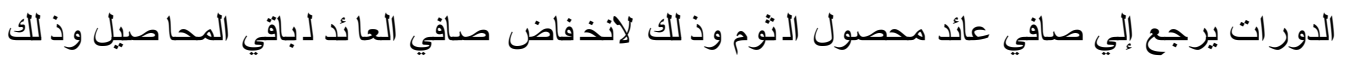

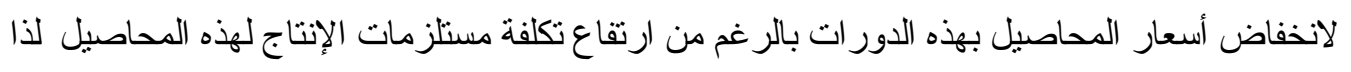

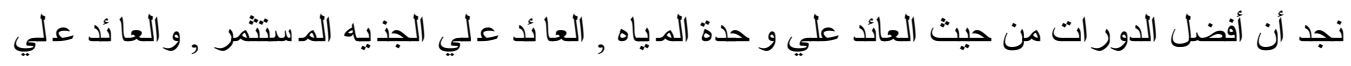

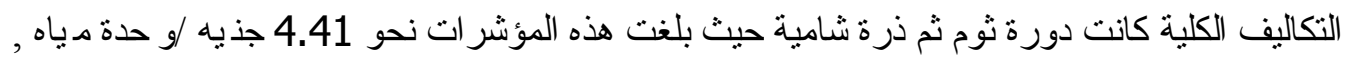

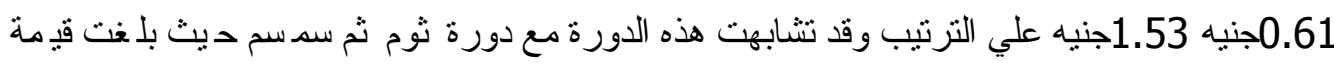

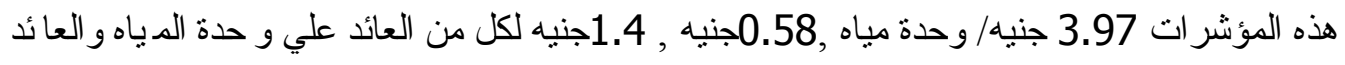

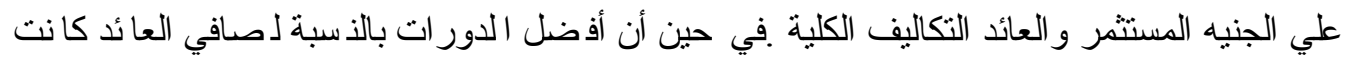

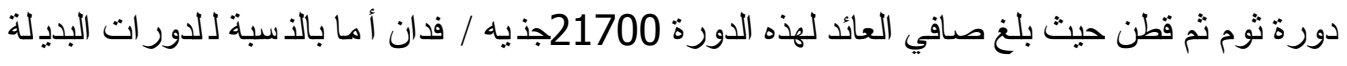

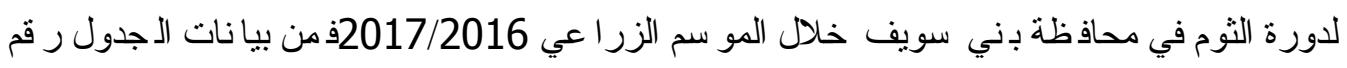

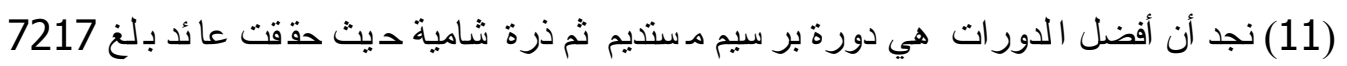

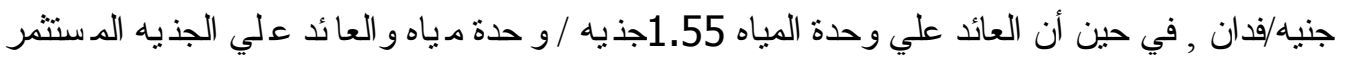

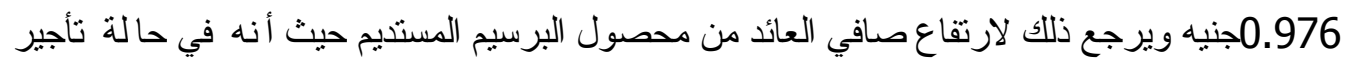

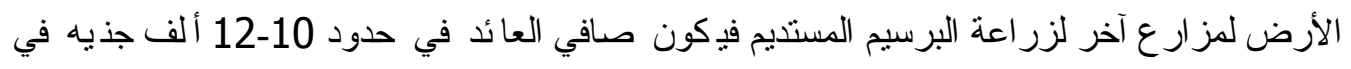

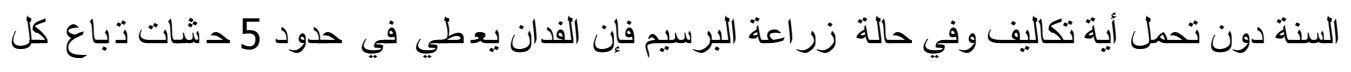

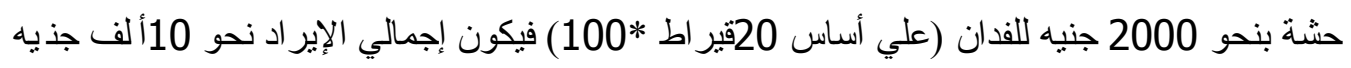

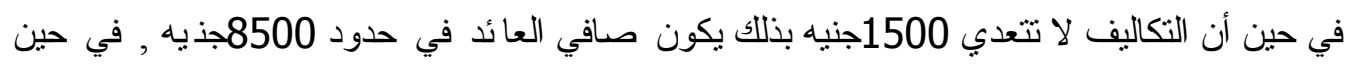

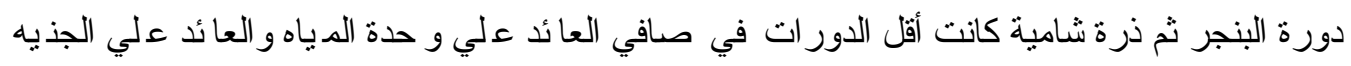

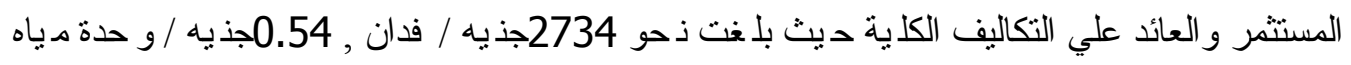
,0.19,

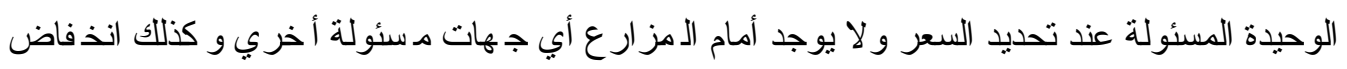

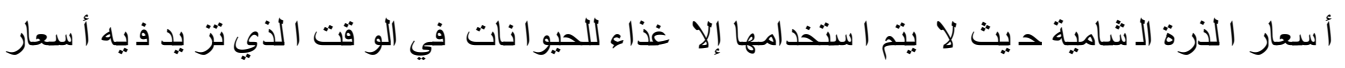

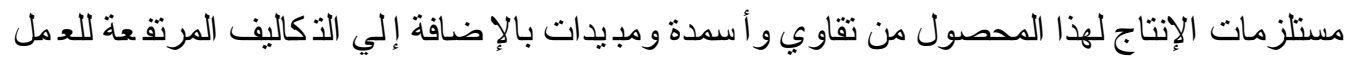

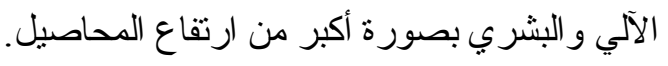


جدول رقم (11) الدورات الأساسية و البديلة بمحافظة بني سويف 2017/2016

\begin{tabular}{|c|c|c|c|c|c|c|}
\hline \multicolumn{3}{|c|}{ الدور ات البديلة } & \multicolumn{3}{|c|}{ الدور ات الأساسية } & \multirow[b]{2}{*}{ البيان البيان } \\
\hline شرسيم+ ذرة & سمسل+ & بنجر + ذرة & توم+سمسم & ثوم+ قطن & ثُم+مية ذرة & \\
\hline 13314 & 22100 & 14150 & 34033 & 39483 & 33933 & (جنيد/فدان) \\
\hline 4677 & 9396 & 3716 & 6458 & 7783 & 5686 & 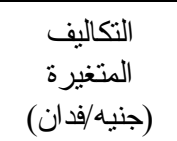 \\
\hline 2720 & 6700 & 7700 & 7700 & 10000 & 7700 & (جنيه/فدان) التكابن \\
\hline 7397 & 16096 & 11416 & 14158 & 17783 & 13386 & (جنيه/فدان) الكلية \\
\hline 7217 & 6004 & 2734 & 19875 & 21700 & 20547 & صنيةفي العاند \\
\hline 1.55 & 1.21 & 0.54 & 3.97 & 3.66 & 4.41 & وحندة المياّة \\
\hline 0.976 & 0.27 & 0.19 & 0.58 & 0.55 & 0.61 & الجنيه المستثر علي \\
\hline 0.976 & 0.37 & 0.24 & 1.40 & 1.22 & 1.53 & التكاليف الكلية \\
\hline
\end{tabular}

المصدر:جمت وحسبت من بيانات مديرية الزراعة بيني سويف ـ سجلات قسم الاحصاء بيانات غير منشورة. توصيف عينة الاراسة : اتضح من عينة الدر اسة المأخوذة خلال الموسم الزر اعي 2017/2016أن منتوسط حجم الحيازة بالعينة

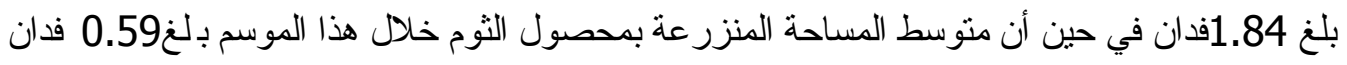

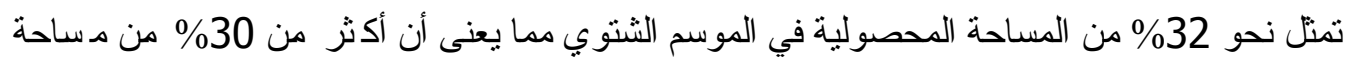

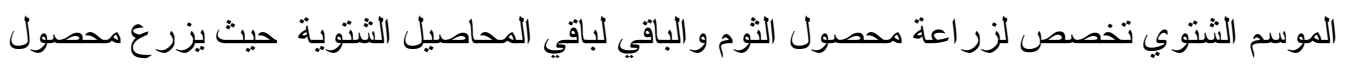

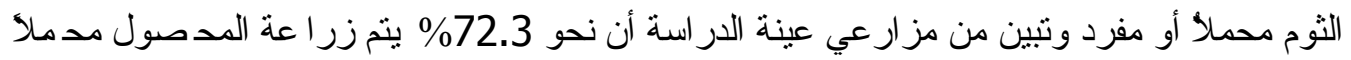

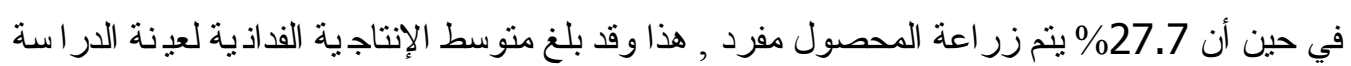

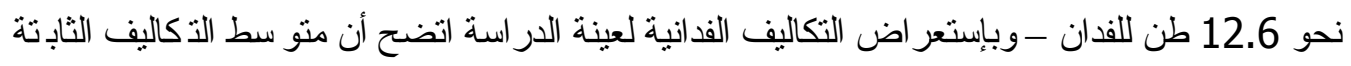
و التي تمثل الإيجار بلغت نحو 9230.54جنيه/ فدان تمنل ذحو 32.62\% من منو سط التكاليف الكاية

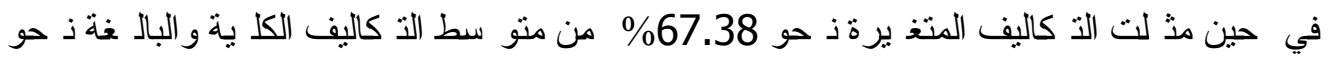

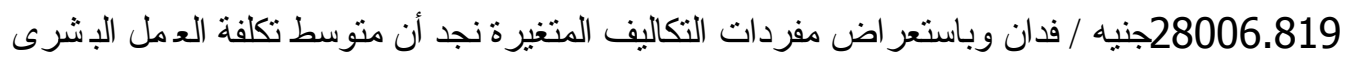

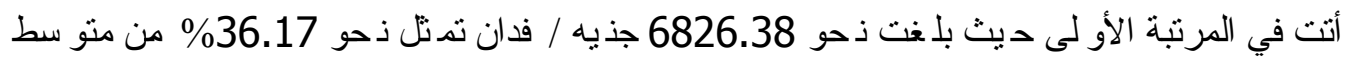

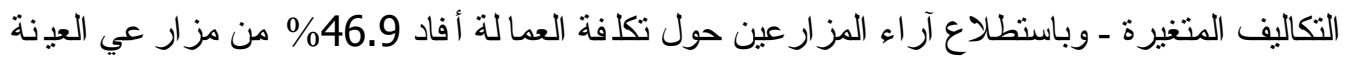

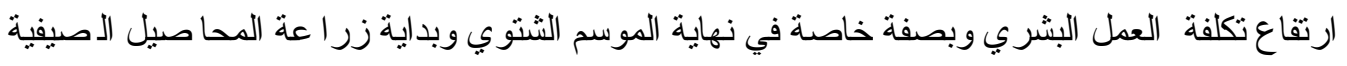




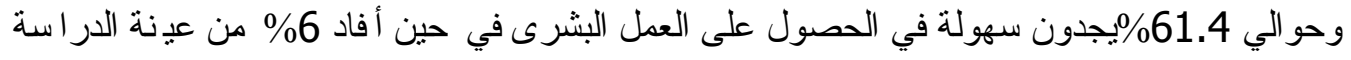

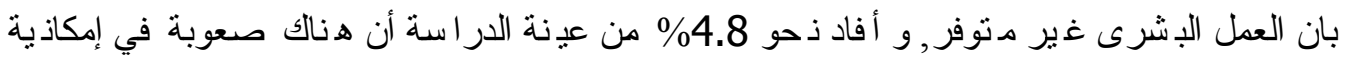

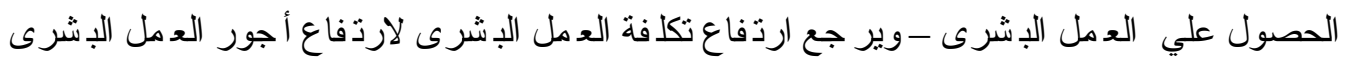

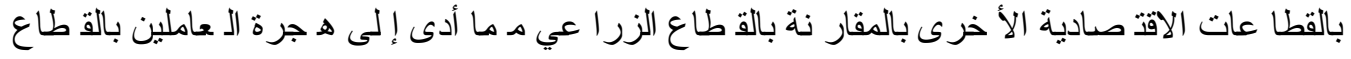

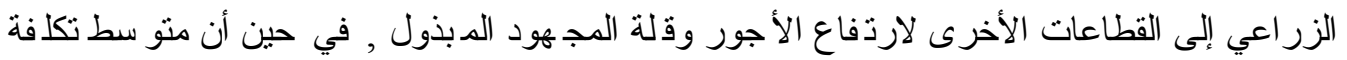

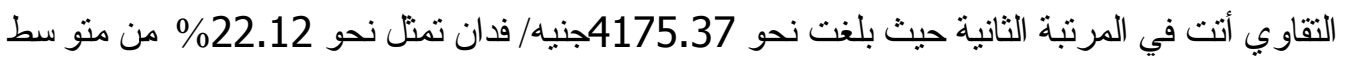

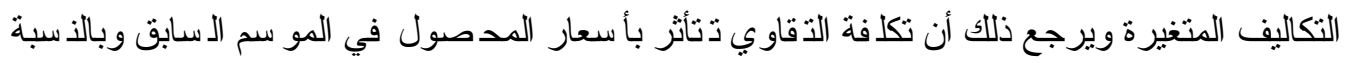

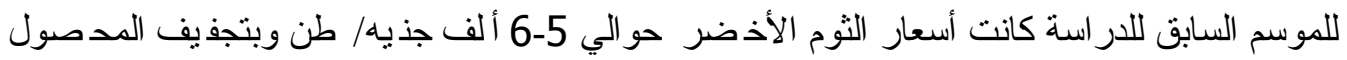

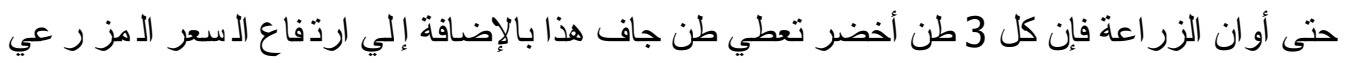

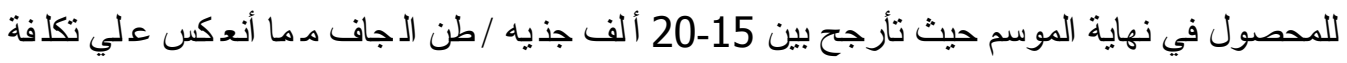

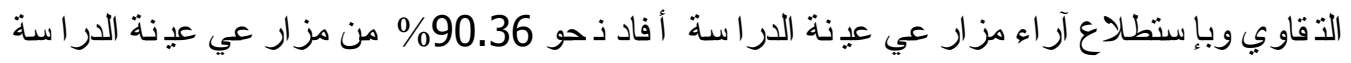

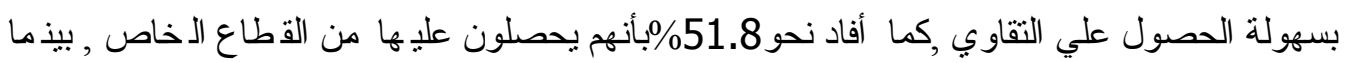
39.7\% من مز ارعي العينة يستخدم تقاوي من محصول الموسم السابق ,حيث عادةُ ما يقوم المز ارعين

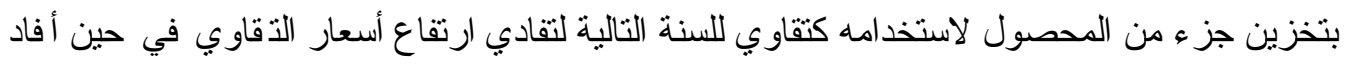

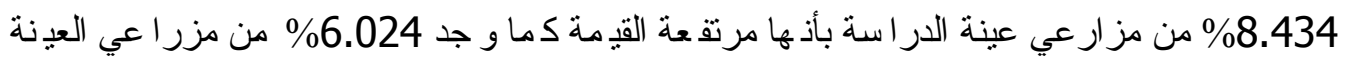

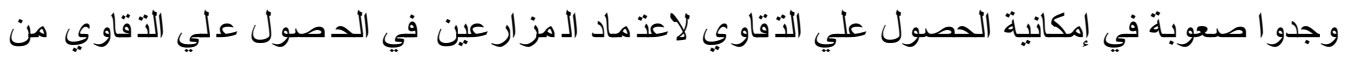

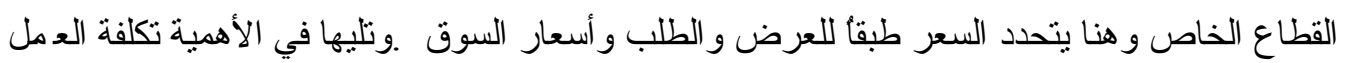

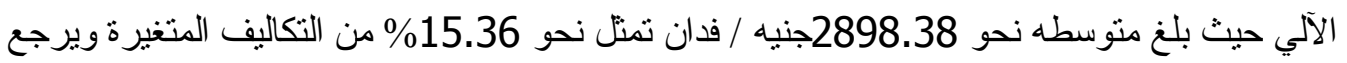

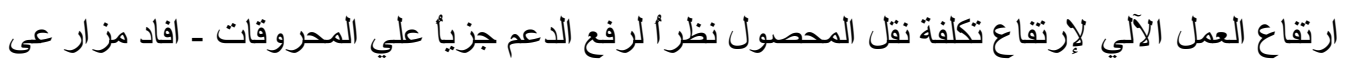

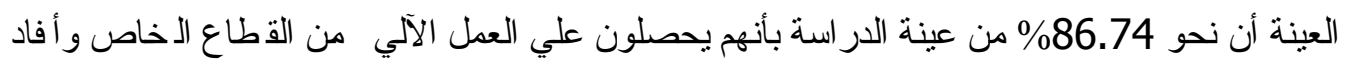

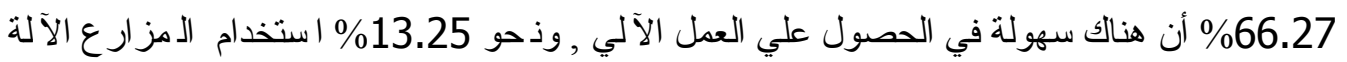

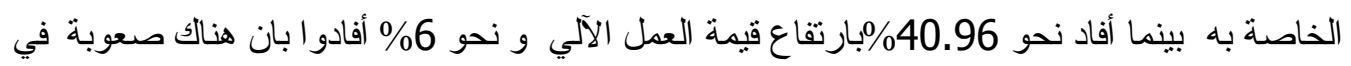

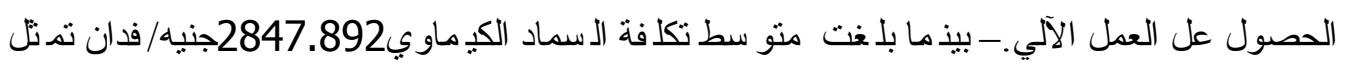

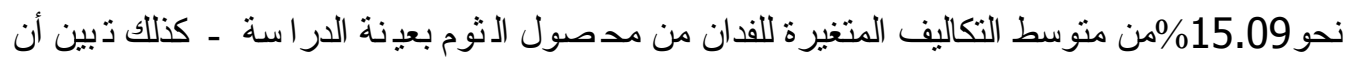

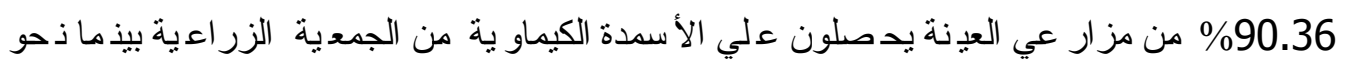

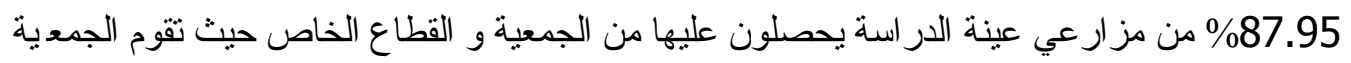
بصرف مقرر ات سما دية أقل من احتياجات المحصول الفعلية ويقوم المز ارعين باستكمال إحتياجتهم من

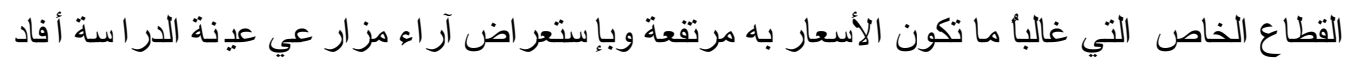

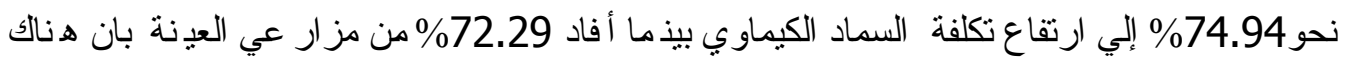

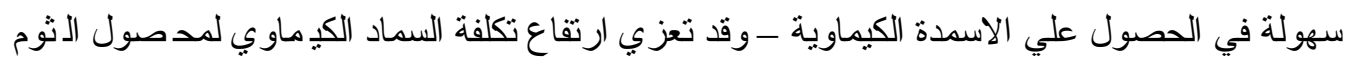

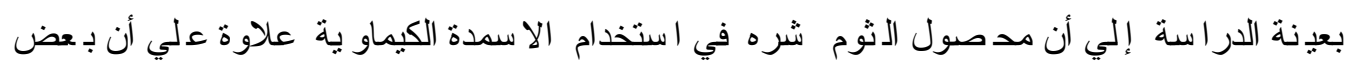

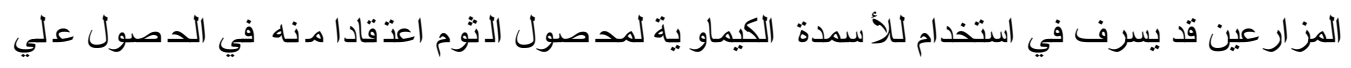

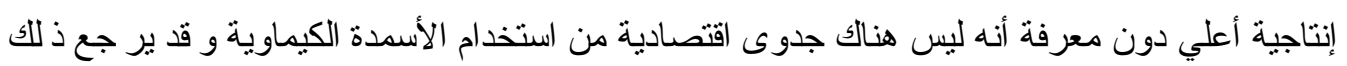

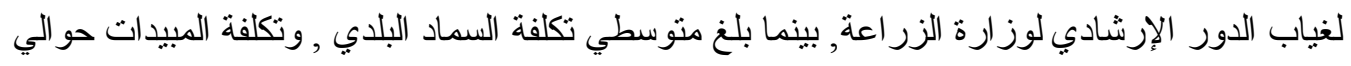

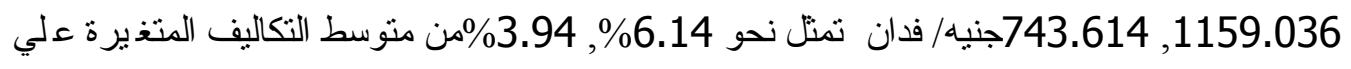

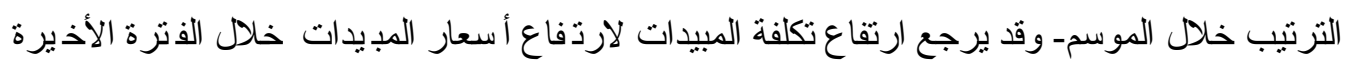

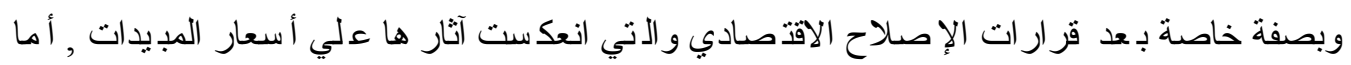


بالنسبة للسماد البلدي فإنه يستخدم بكميات محدودة حيث إنه غير مرغوب باستخدامه في هذا المدصول

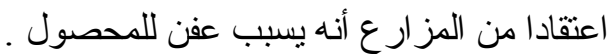

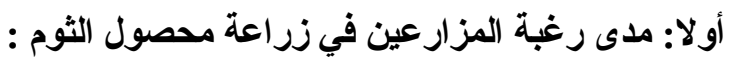

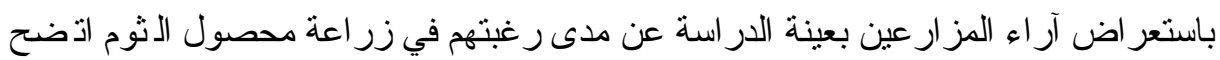
أن نحو 81.9\% من عينة الدر اسة أبدو رغبتهم في زر اعة المحصول حيث أفاد ذحو 73.49\% منهم

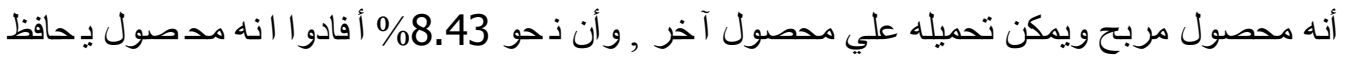

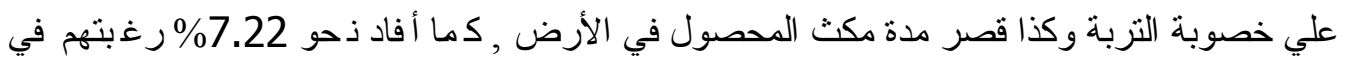

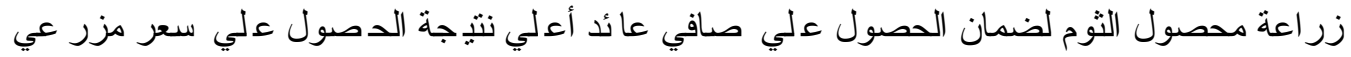

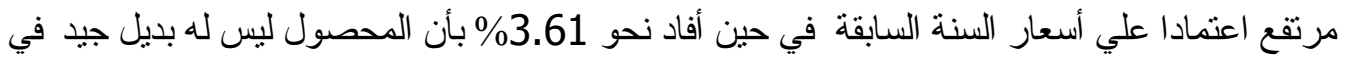

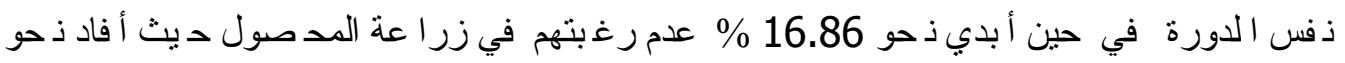

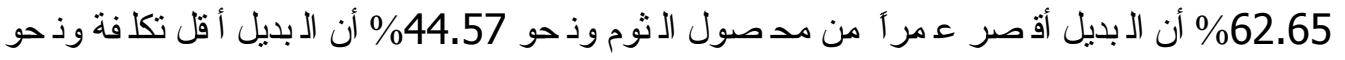

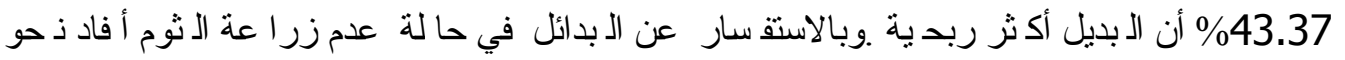

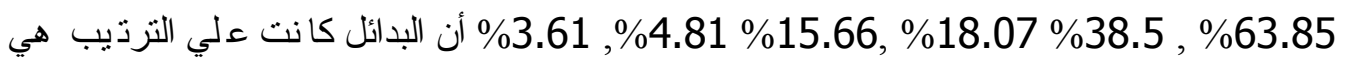

محاصيل القمح , البرسيم المستديم , محاصيل خضر , بنجر السكر , الحلبة ثانياً : التسويق :

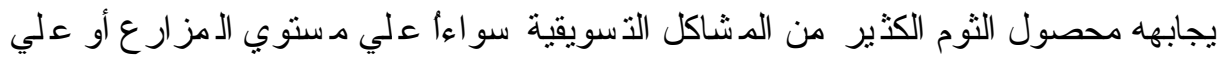

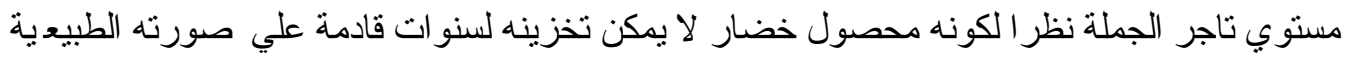

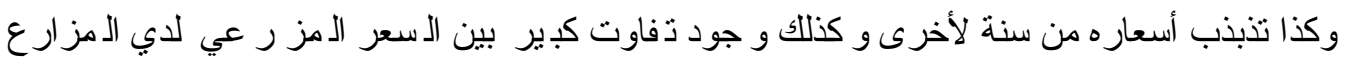

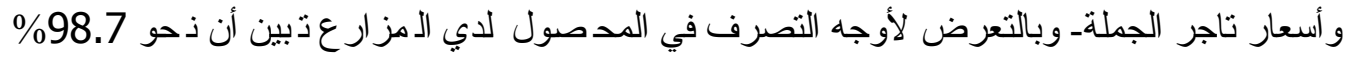

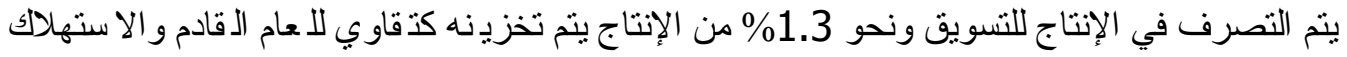

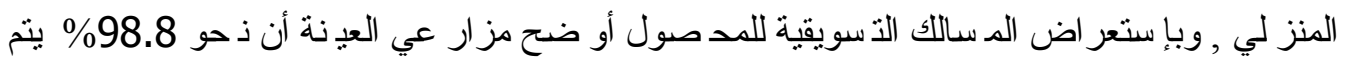

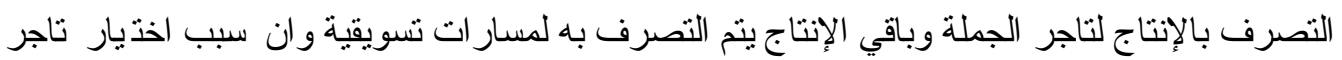

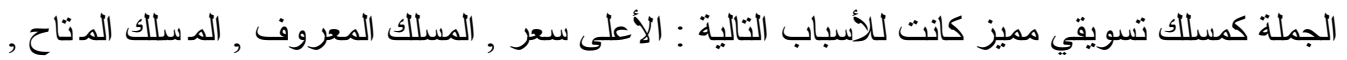

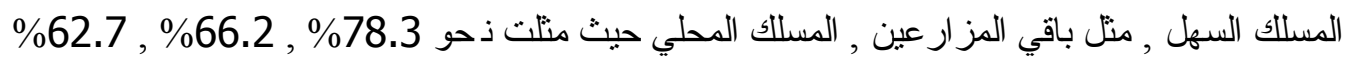

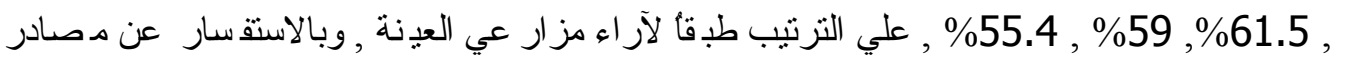

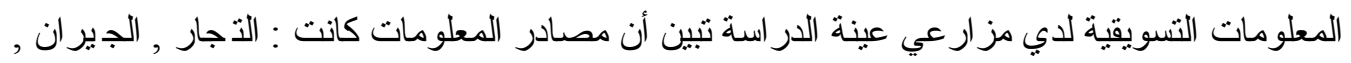

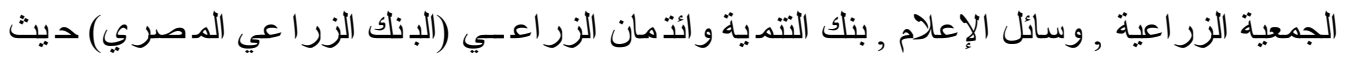

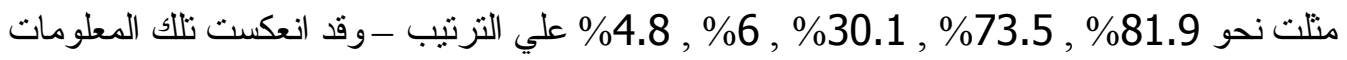

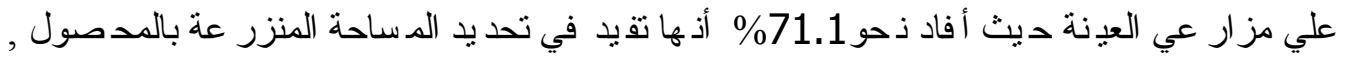

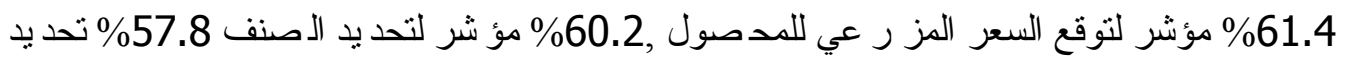

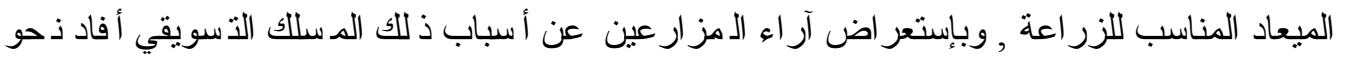

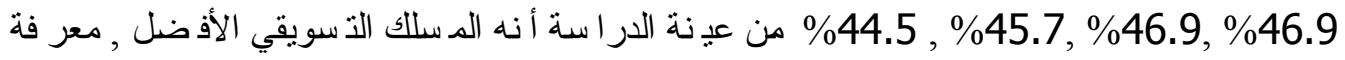
مميز ات و عيوب كل سوق , الحصول علي أفضل الأسعار , البيع في الميعاد الذي يحقق أعلي سعر .

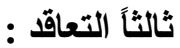
يعتبر التعاقد أحد المسارات التسويقية بل وقد يكون من أهمها و التي علي أساسها يتم اتخاذ

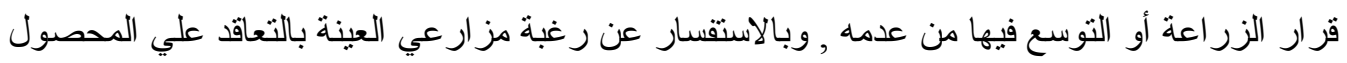

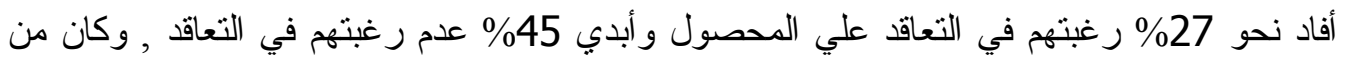


أسباب الرغبة في التعاقد علي المحصول الحصول علي صافي عائد جيد 39\% ونحو 30\% ضمان

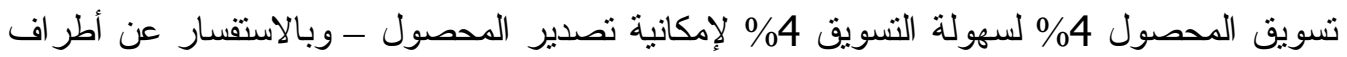

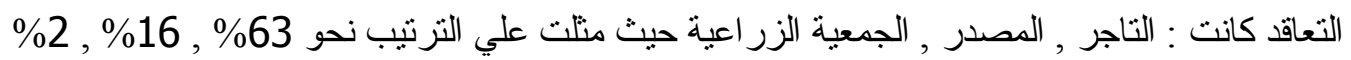

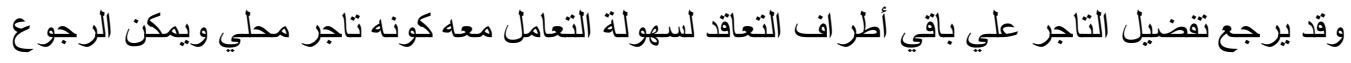

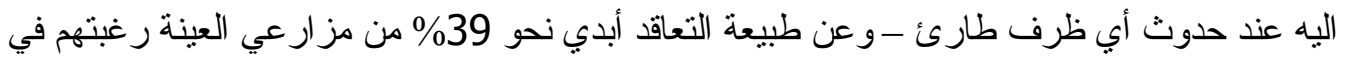
تسليم المحصول بالكامل ونحو 48\% نسليم جزء من المحصول و والاحتفاظ بالباقي للاستهلاك العائلي مني

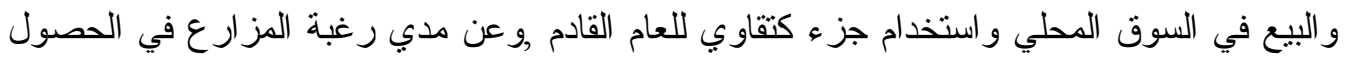

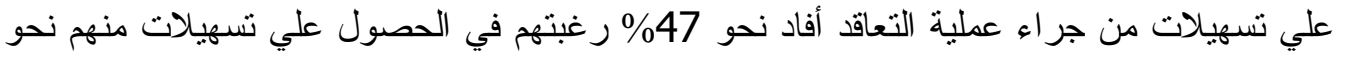

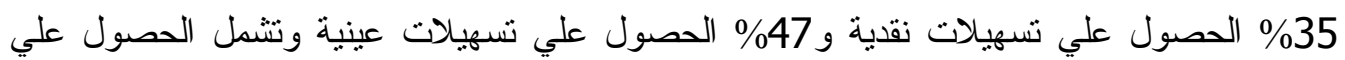

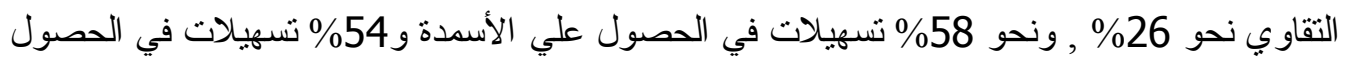

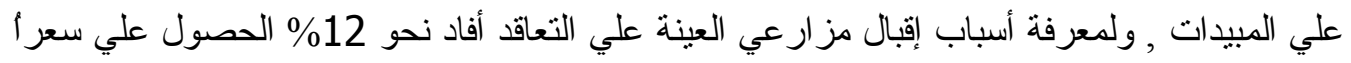

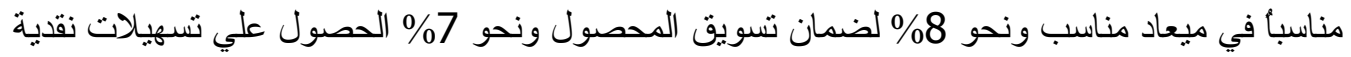

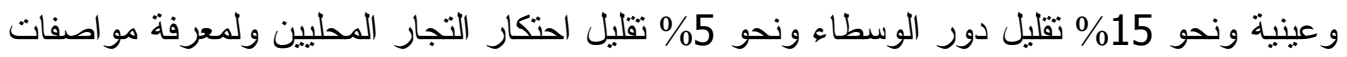

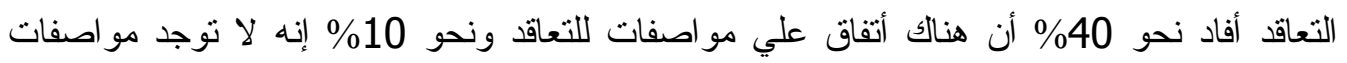

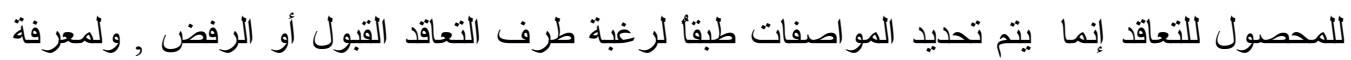

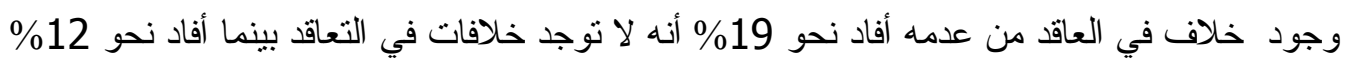

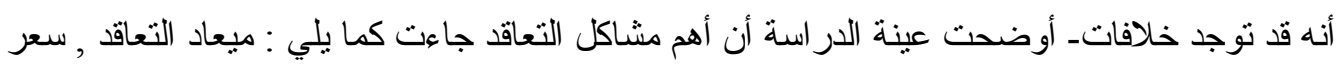

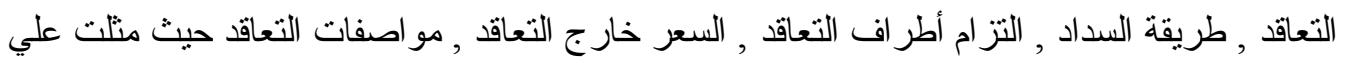

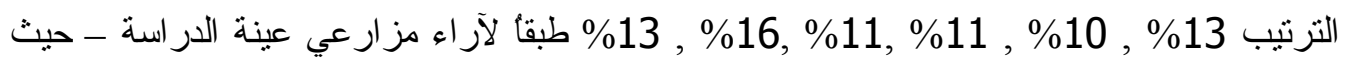
أبدي مزارعي العينة أنه يجب أن يتم التعاقد علي المحصول قبل ميعاد الزر اعة بوقت كاف حتى يتمكن

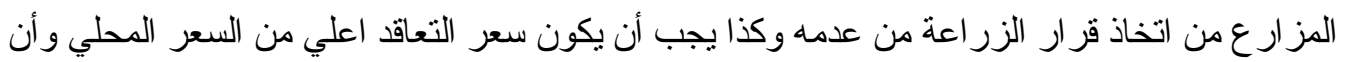

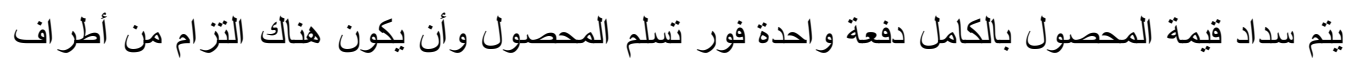
التعاقد و أن يشترك المز ارع في مو اصفات المحصول المتعاقد عليه. رابعأ:المشكلات الإتتاجية والتسويقية بعينة الار استة :

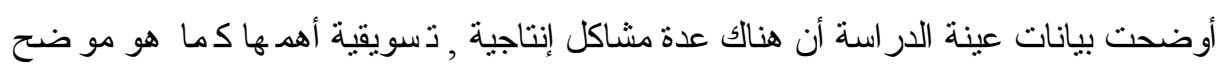

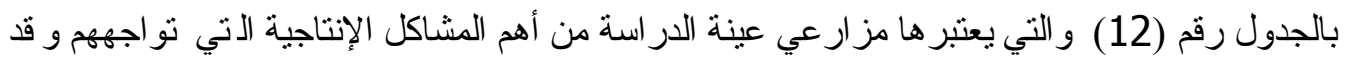

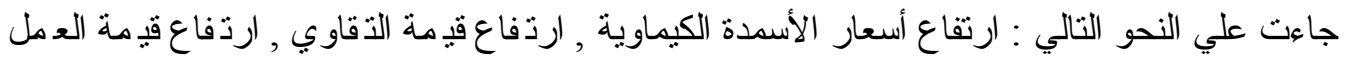

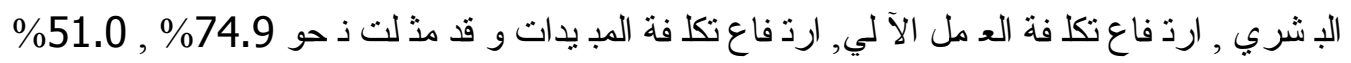
\% 13.0, \%40.9, \%46.9,

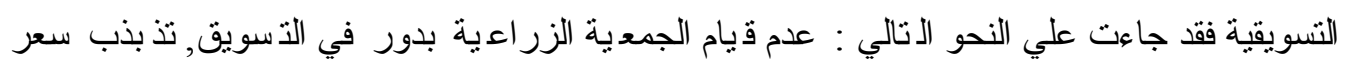

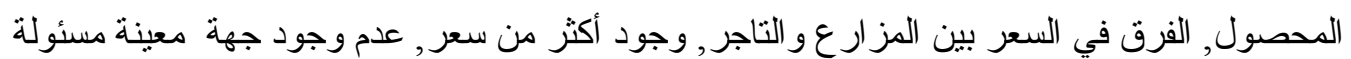

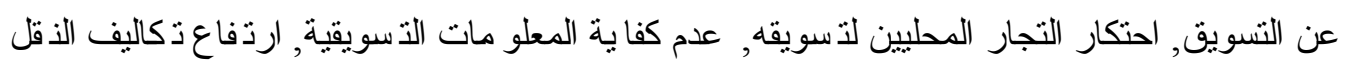

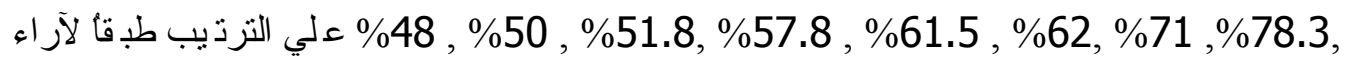


جدول رقم (12) ترتيب المشاكل الإنتاجية و التسويقية بعينة الدراسة بمحافظة بني سويف

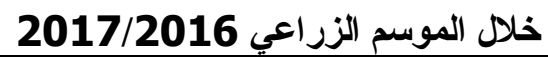

\begin{tabular}{|c|c|c|c|c|c|}
\hline \multicolumn{2}{|c|}{ آراء المزارعين } & \multirow{2}{*}{ المشاكل التسويقية } & \multicolumn{2}{|c|}{ آراء المزارعين } & \multirow{2}{*}{ المشاكل الإتتاجية } \\
\hline$\%$ & عدد & & $\%$ & عدد & \\
\hline 78.3 & 65 & 1- عدم قيام الجمعية الزر اعية بدور في التسويق & 74.9 & 75 & 1- ارتفاع أسعار الأسدة الكيماوية \\
\hline 71.0 & 59 & 2- تذبذب سعر المحصول & 51.0 & 42 & 2- 2- ارتفاع قيمة الثقاو ي \\
\hline 62.0 & 52 & 3ـ الفرق في السعر بين المز ارعو التاجر & 46.9 & 39 & 3- ارتفاع أجور العمل البشري \\
\hline 61.5 & 51 & 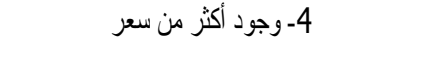 & 40.9 & 34 & 4- ارتقاع تكلةة العمل الآلي \\
\hline 57.8 & 48 & 5- عدم وجود جهة معينة مسئولة عن التسويق & 13.0 & 11 & 5- ارتفاع تكلفة المبيدات \\
\hline 51.8 & 43 & 6- احتكار التجار & & & \\
\hline 50.0 & 42 & 7- عدم كفاية المعلومات النسويقية & & & \\
\hline 48.0 & 40 & 8- ارتقاع تكاليف النقل & & & \\
\hline
\end{tabular}

المصدر : جمعت وحسبت من استمار ات الاستبيان الخاصة بالدراسة .

\section{الوضع الر اهن للصادرات من محصول الثوم المصري:}

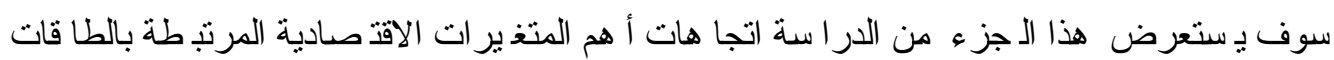

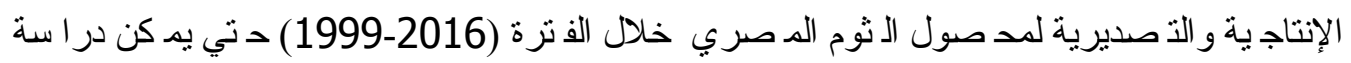

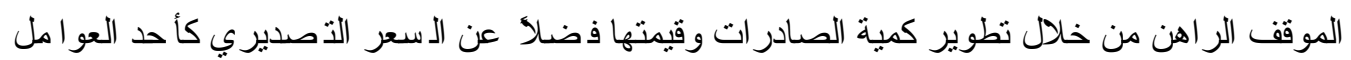

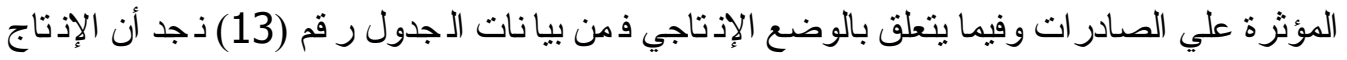

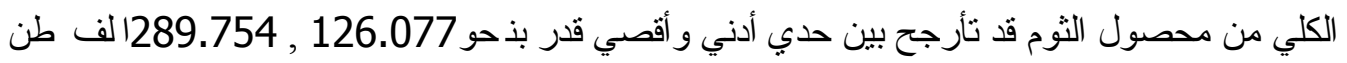

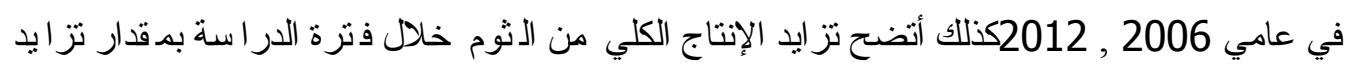

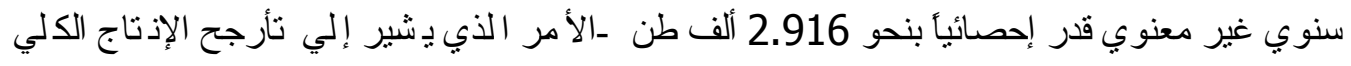

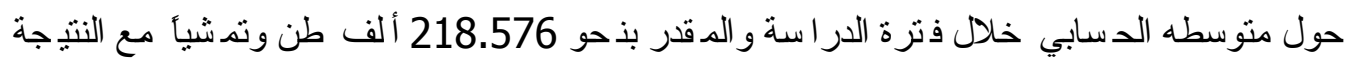

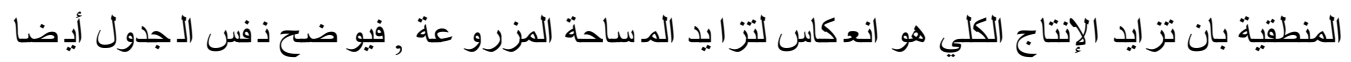

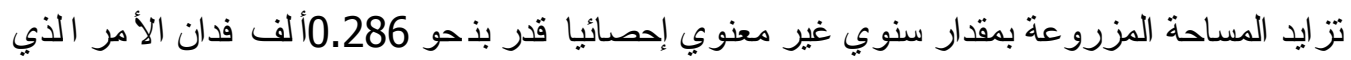

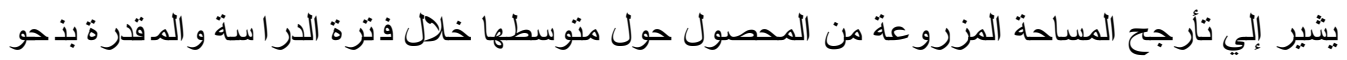

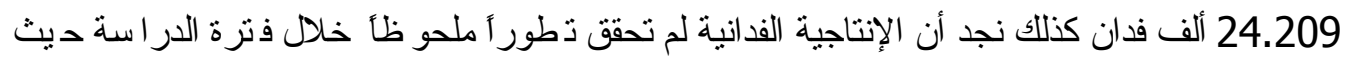

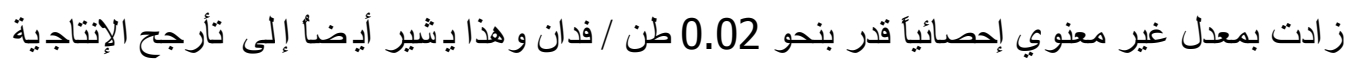

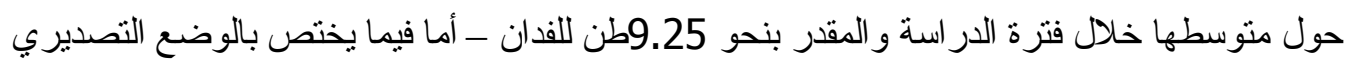

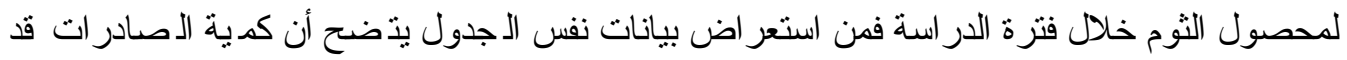

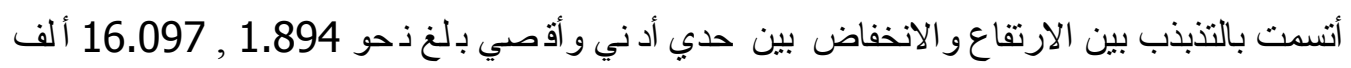

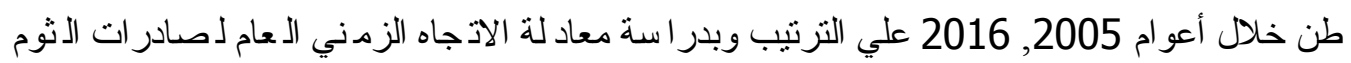

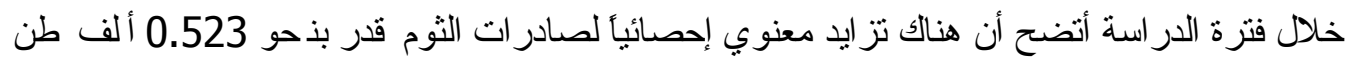

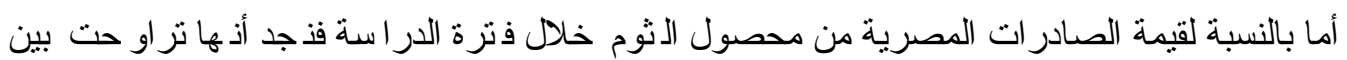
786.78ألف دولار عام 1999 كحد ادني وذحو 1923.592 ألف دولار كحد أقدي عام 2016 
898

"ECONOMIC STUDY FOR THE PRODUCTION AND

MARKETING OF GARLIC CROP IN EGYPT

(STUDY CASE FOR BENI SUEF GOVERNORATE)"

بمتوسط قدر بنحو 524.799 ألف دو لار خلال فنزة الدر اسة من خلال معادلة الاتجاه الزمني الـعام

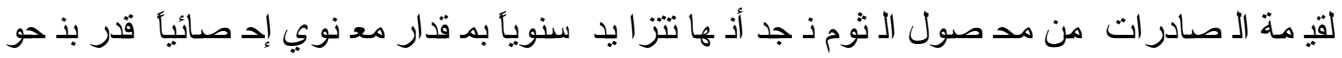

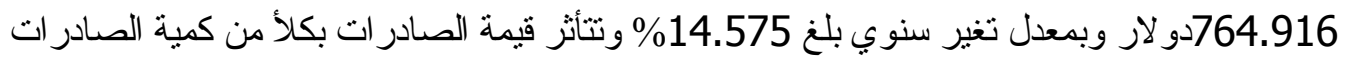
وسعر التصدير حيث أن هناك تز ايد معنوي إحصائياً لكمية الصادرات كذلك هناك تز ايد معنوي إحصائياً لسعر الصادر ات قدر بنحو 63.488دو لار / طن خلال فترة الدر اسة وبمعدل تغير سنوي بـلغ 8.812

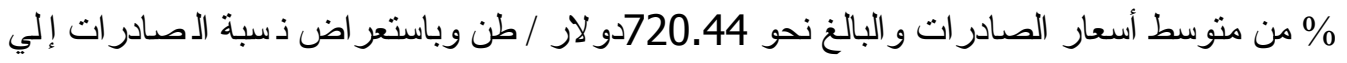

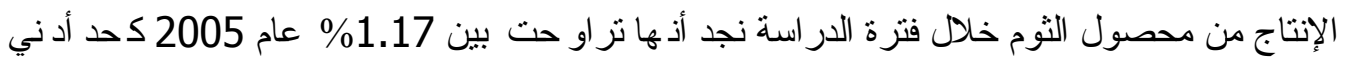

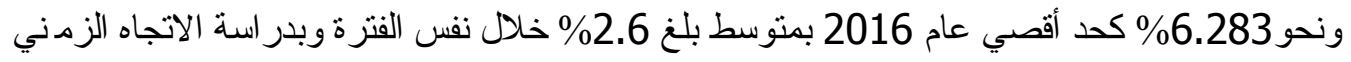

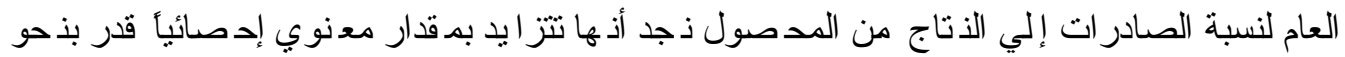
0.185 \% خلال فترة الدر اسة . جدول رقم (13) بعض المتغيرات الاقتصادية لمحصول الثوم المرتبطة بالطاقات الإتتاجية و التصديرية

\begin{tabular}{|c|c|c|c|c|c|c|c|}
\hline \multicolumn{8}{|c|}{ في الفترة (1999- 2016) } \\
\hline 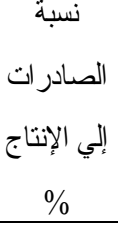 & قبمة الصادر ات باد & دولار /لصادرات & طمبة طبادرات & الإنتاج طن & طن/ الإنتاجية & بالفدان & 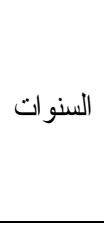 \\
\hline 1.30 & 786.780 & 270 & 2914 & 224133 & 8.729 & 25677.6 & 1999 \\
\hline 1.32 & 1328.500 & 250 & 5314 & 266555 & 8.870 & 30050.4 & 2000 \\
\hline 1.99 & 986.340 & 230 & 4288 & 215420 & 9.656 & 22310.4 & 2001 \\
\hline 1.61 & 1411.930 & 430 & 3051 & 190000 & 9.136 & 20796.0 & 2002 \\
\hline 3.43 & 3353.920 & 470 & 7136 & 207757 & 9.104 & 22821.6 & 2003 \\
\hline 2.27 & 2349.600 & 550 & 4272 & 187833 & 9.374 & 20037.6 & 2004 \\
\hline 1.17 & 909.120 & 480 & 1894 & 162077 & 9.449 & 17152.8 & 2005 \\
\hline 1.24 & 845.460 & 420 & 2013 & 164260 & 9.414 & 17448.0 & 2006 \\
\hline 1.77 & 1865.250 & 450 & 4145 & 234570 & 9.360 & 25060.8 & 2007 \\
\hline 2.85 & 3754.110 & 510 & 7361 & 201470 & 7.145 & 28197.6 & 2008 \\
\hline 1.735 & 3997.889 & 1390 & 3031 & 174657 & 10.009 & 17450.0 & 2009 \\
\hline 3.334 & 6395.810 & 891 & 7394 & 120896 & 9.590 & 23034.0 & 2010 \\
\hline 4.813 & 11454.330 & 865 & 13242 & 275106 & 9.514 & 28916.0 & 2011 \\
\hline 4.112 & 15325.262 & 1286 & 11917 & 289754 & 9.897 & 29277.0 & 2012 \\
\hline 2.801 & 7875.153 & 1287 & 6119 & 218428 & 9.860 & 22153.0 & 2013 \\
\hline 2.591 & 4930.208 & 688 & 7166 & 276556 & 9.433 & 26183.0 & 2014 \\
\hline 2.182 & 7658.384 & 1306 & 5864 & 268715 & 9.231 & 29961.0 & 2015 \\
\hline 6.283 & 19235.915 & 1195 & 16097 & 256189 & 8.761 & 29242.0 & 2016 \\
\hline 2.600 & 5247.997 & 720.44 & 6289.89 & 218576.4 & 9.25 & 24209.39 & المتوسط \\
\hline
\end{tabular}


جدول رقم (14) معادلات الاتجاه الزمني العام للمؤشرات الإتتاجية والتصديرية لمحصول الثوم

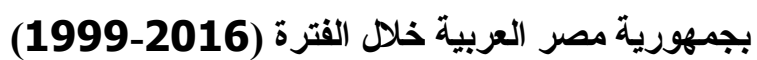

\begin{tabular}{|c|c|c|c|c|c|c|}
\hline 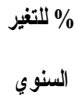 & التتوسط & 2ر & ن & نموذج الآجاه الزمني العام & البيان & p \\
\hline 1.18 & 24.209 & 0.060 & 2.083 & 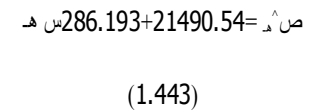 & المسادة & 1 \\
\hline 2.16 & 9.250 & 0.028 & 0.460 & 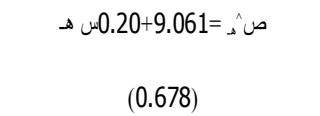 & الإتاجية & 2 \\
\hline 1.33 & 218.576 & 0.109 & 1.950 & 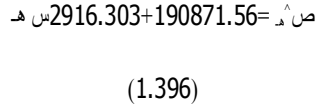 & الإتتاج (لكلي & 3 \\
\hline 8.318 & 6.289 & 0.399 & 10.626 & 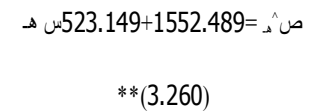 & كية الصادرات (طن) & 4 \\
\hline 8.812 & 720.44 & 0.694 & 36.259 & 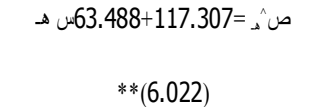 & سعر الصادرات (دولار & 5 \\
\hline 14.575 & 5247.997 & 0.586 & 22.683 & 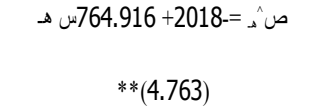 & قيمة الصادرات (الدو لار) & 6 \\
\hline 0.007 & 2.600 & 0.405 & 10.881 & 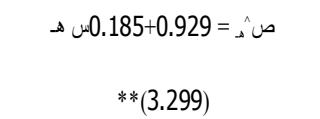 & نسبة الصادرات إلى & 7 \\
\hline
\end{tabular}

المصدر: حسبت وجمعت من بيانات الجدول رقم (13) 


\section{التوصيات}

1- النهوض بالإنتاج من المحصول من حيث الكمية ومو اصفات الجودة طبقأ للتطور الـعالمي بحيث

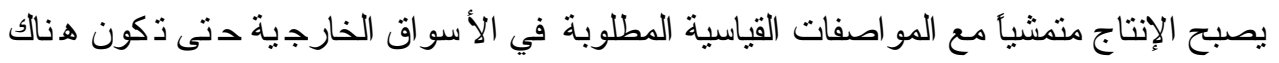

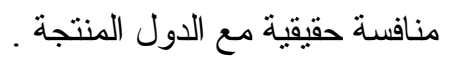

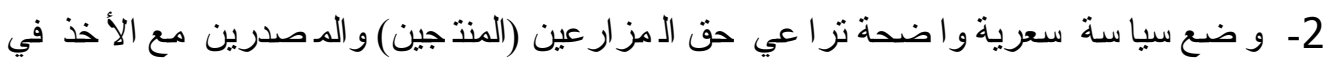

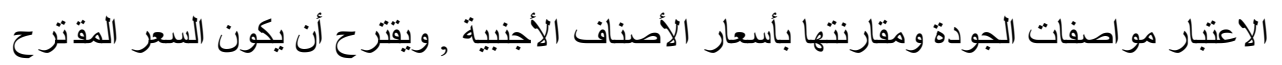

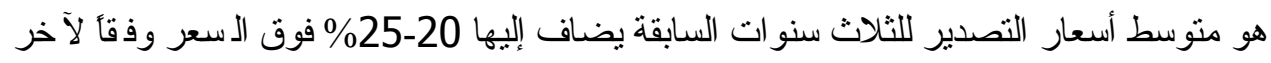
متوسط ثلاث سنو ات .

3- أن تقوم منظمات المجتمع المدني وكذلك الجمعيات التي تعدل في مجال تصدير الـلع الزر اءية

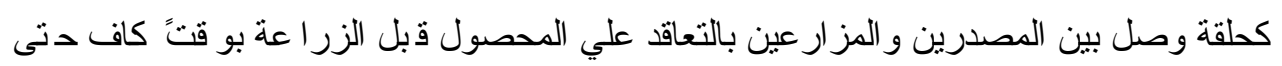

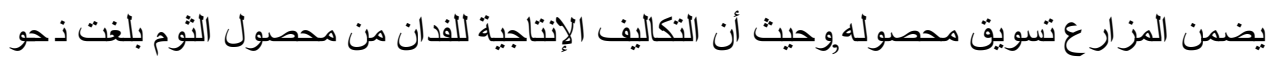

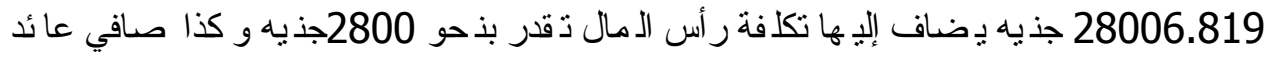

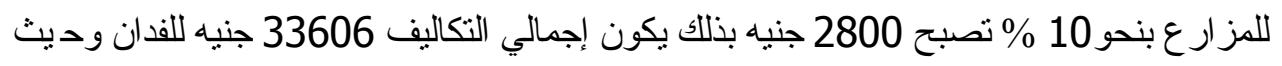

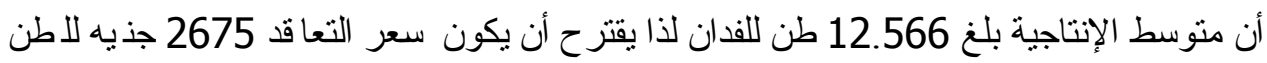

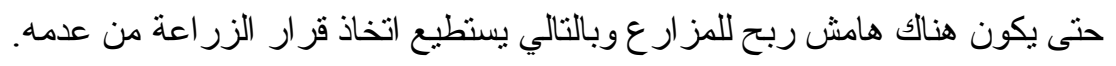

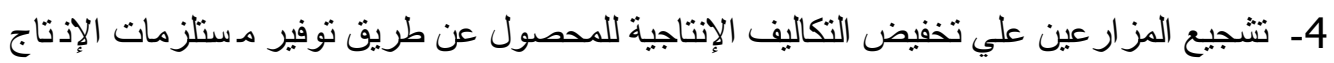

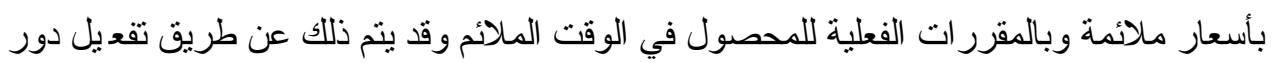
الإرشاد الزر اعي بتو عية المزارعين بالمقرر ات الملائمة للمحصول.

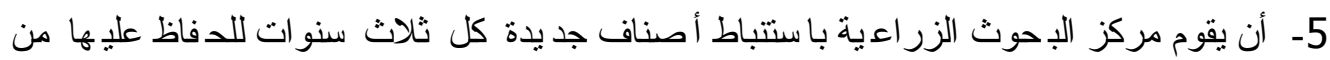

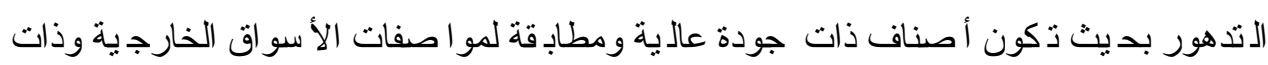

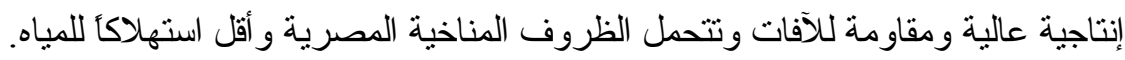

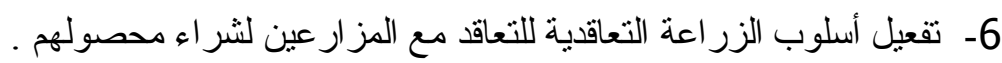

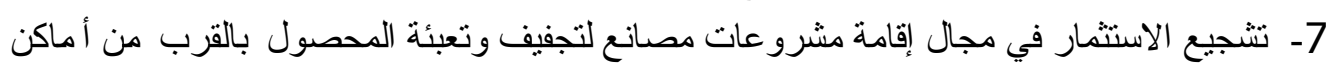

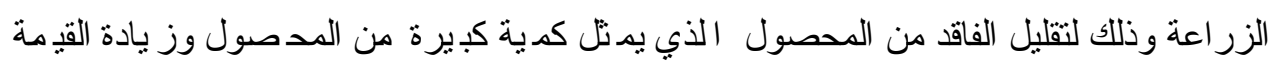




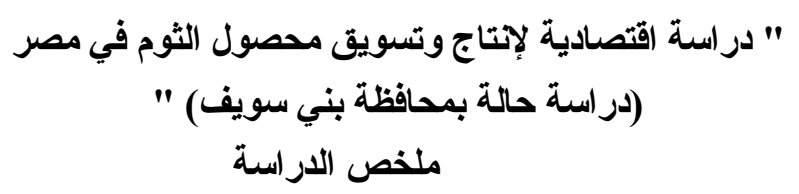

يعتبر محصول الثوم من المحاصيل التصديرية الهامة بمصر و التي تدنل مكانة

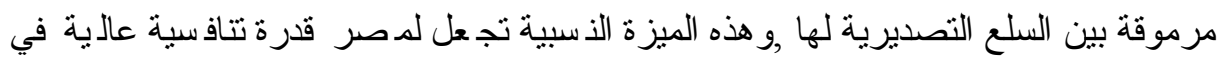

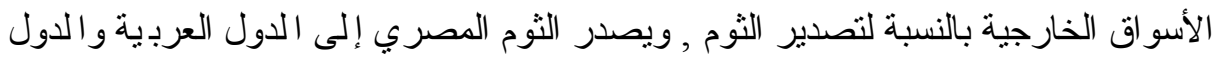

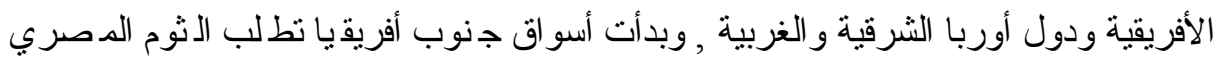

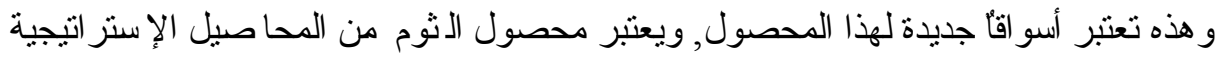

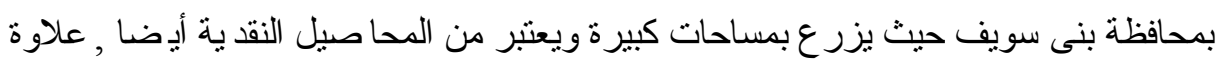

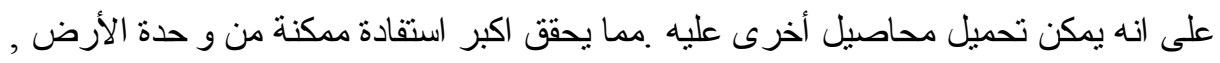

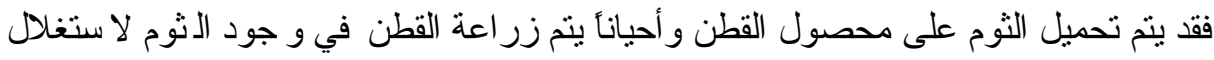

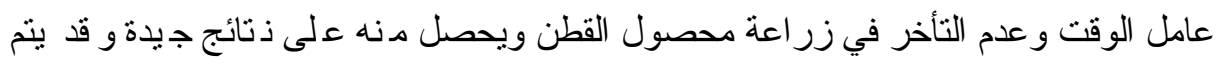

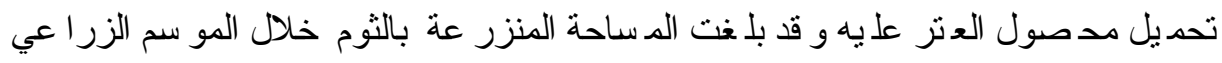

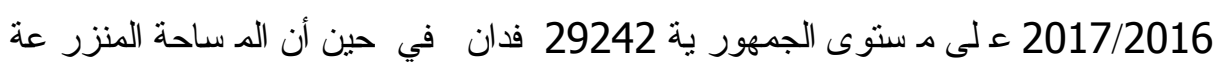

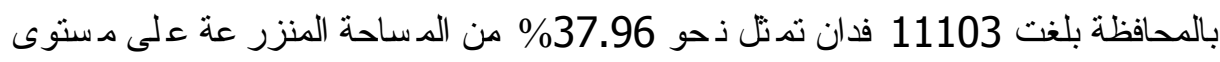

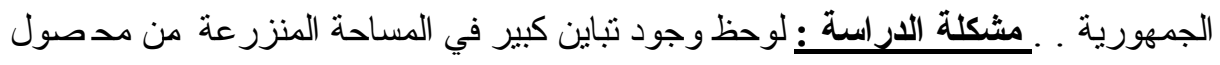

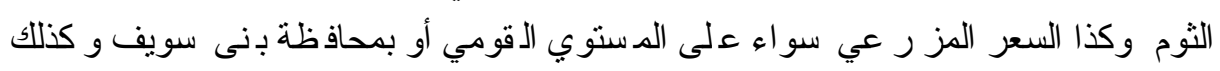

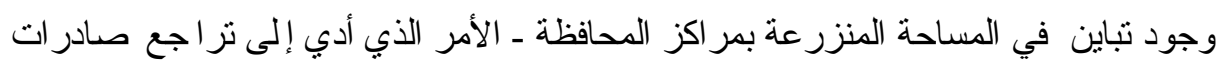

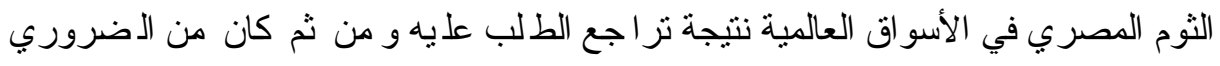

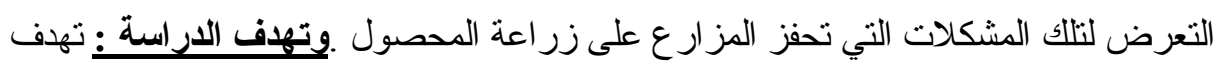

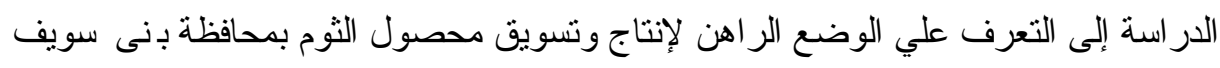

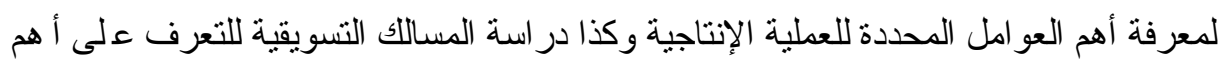

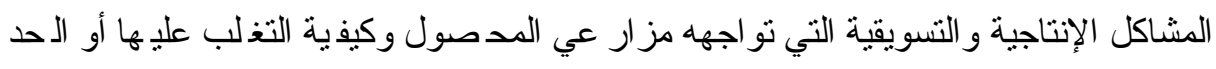

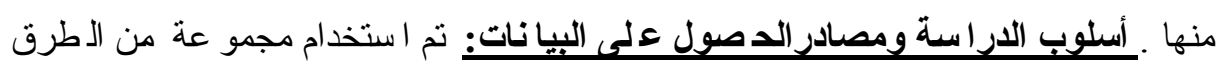

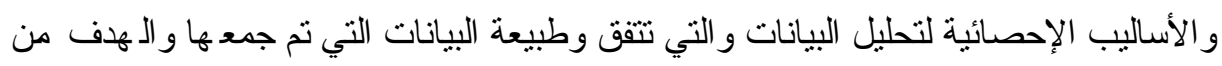

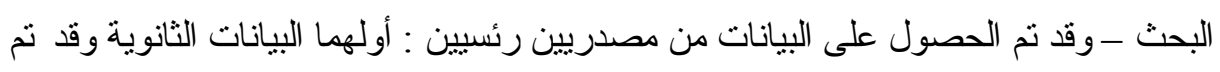

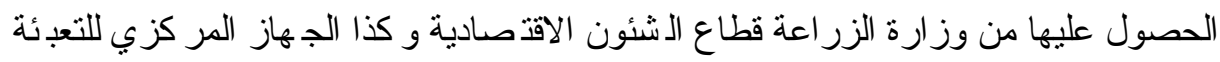

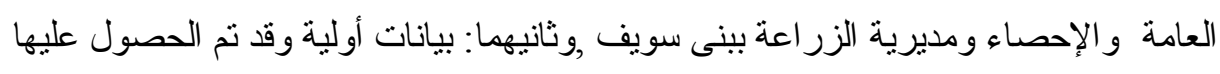

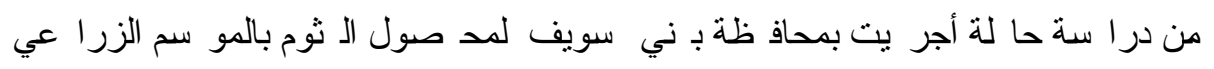

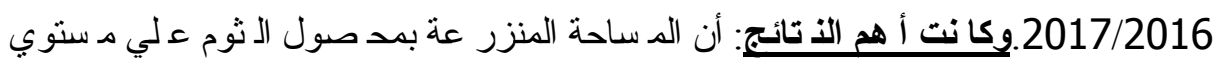

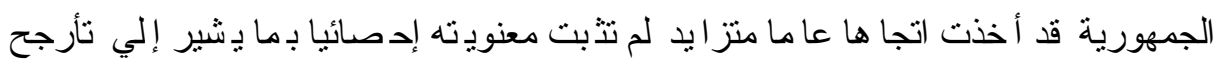
المساحة المنزر عة بالمحصول حول متوسطها الحسابي المقدر بذحو

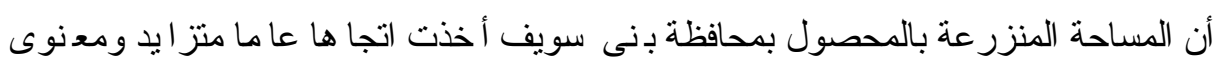

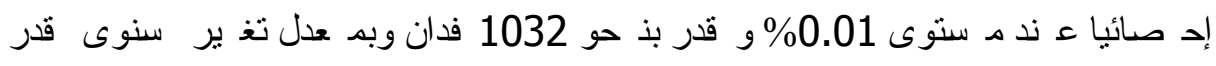

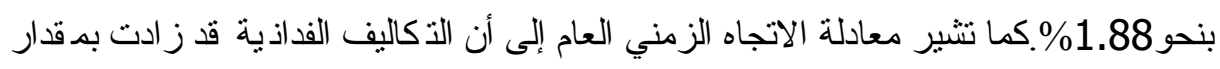

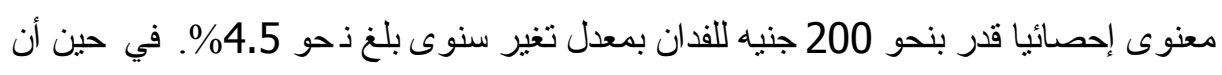

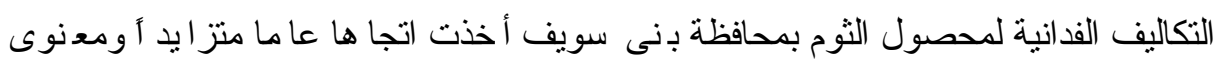


إحصائيا قدر بنحو 100 جنيه/ فدان وبمعدل تغير سنوى بلغ نحو 1.75\%. وتبين من تطور

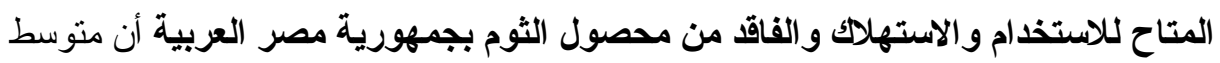

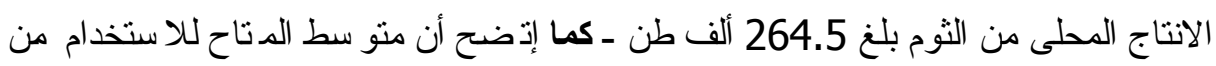

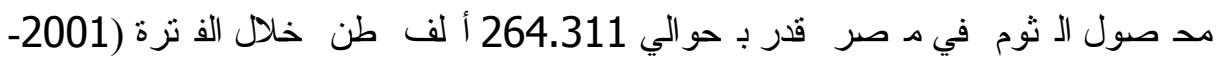

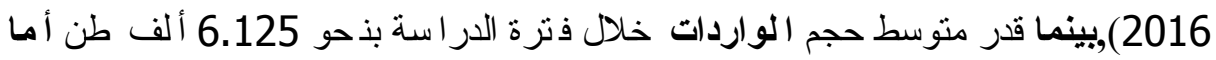

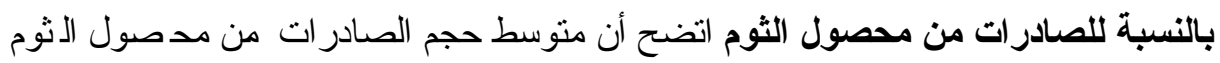

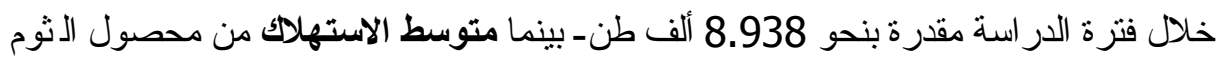

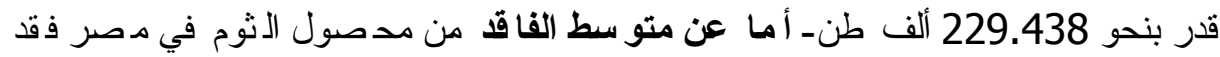

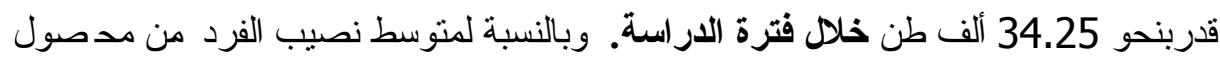

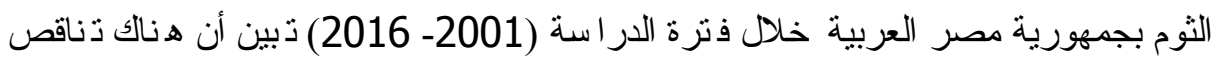

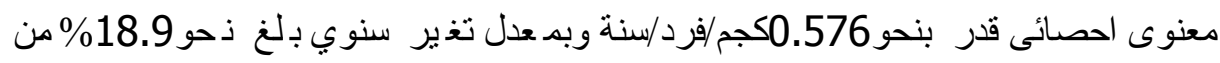

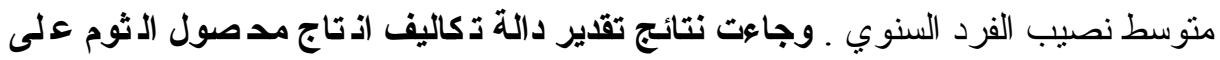

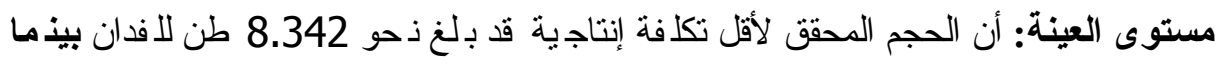

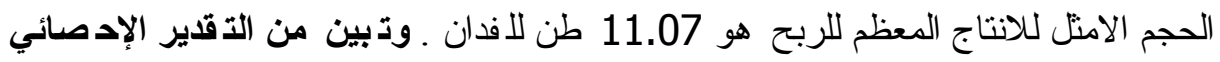

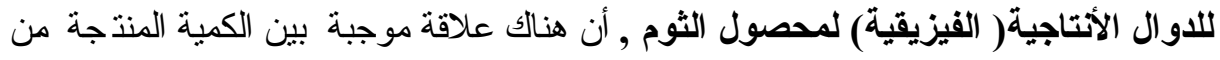

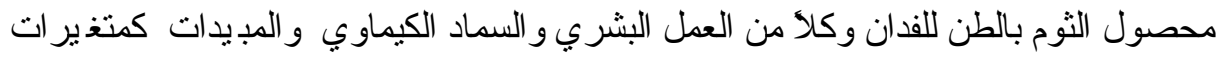

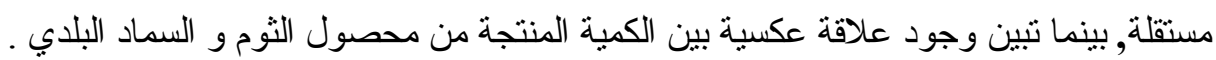

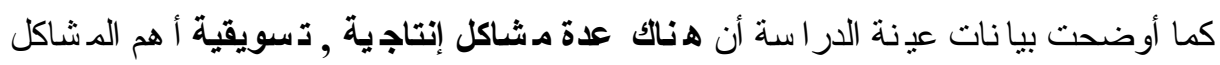

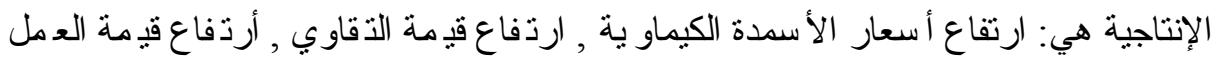

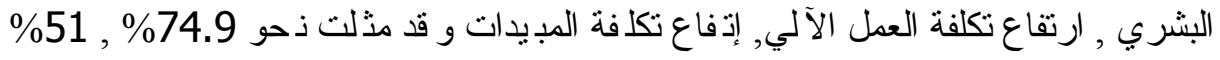

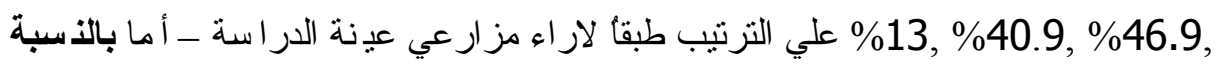

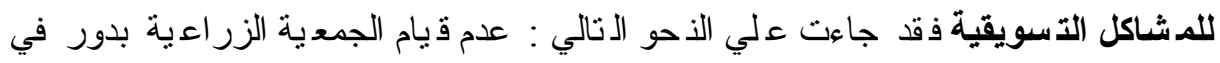

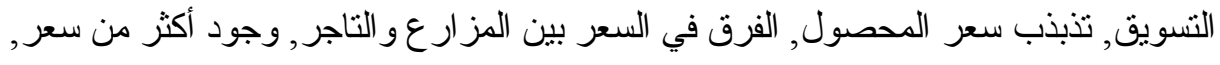

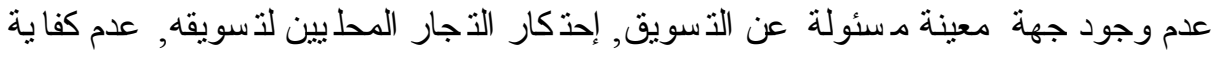

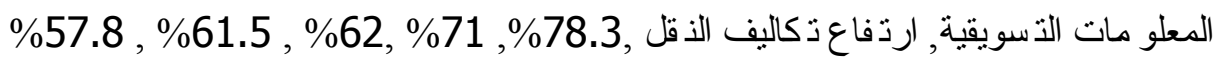

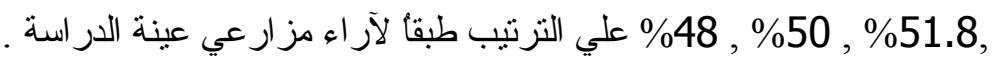




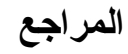

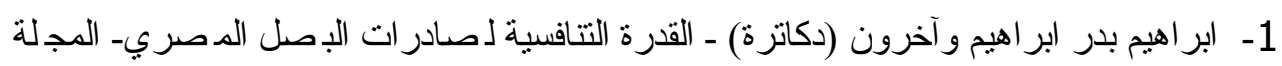

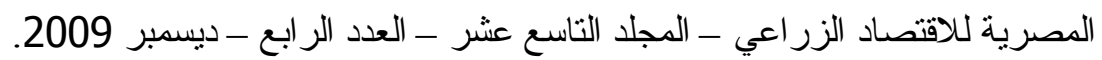
2- الجهاز المركزي للتعبئة العامة و الإحصاء ـ-نشر ات التجارة الخارجيةــ أعداد متقرقة.

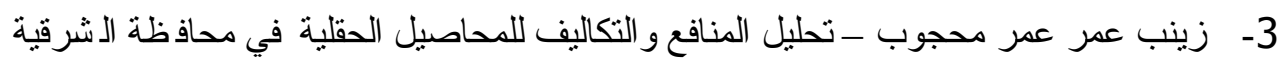

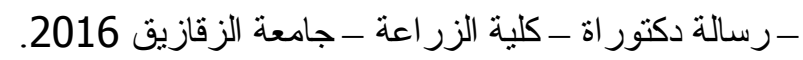

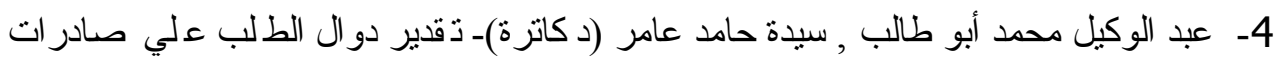

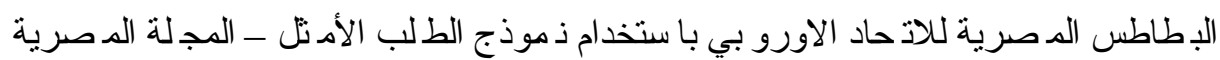

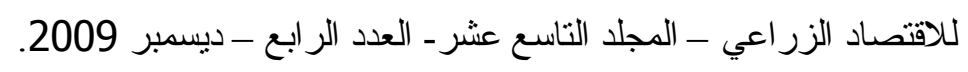

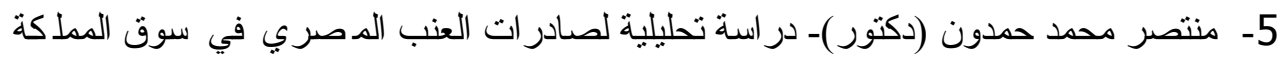

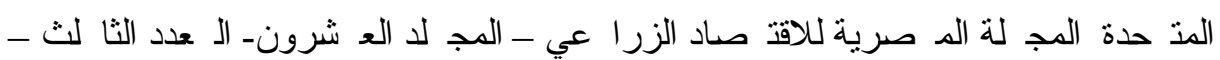

$$
\text { سبتمبر } 2010 .
$$

6- هاني نجيب ألياس (دكتور ) - محاضر ات في التسويق - مع هـ بـوث الاقتصاد الزراعي 2002

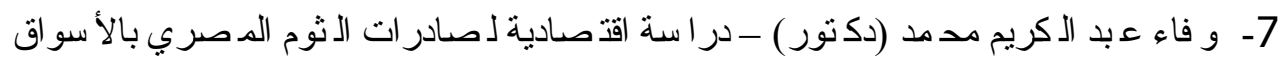

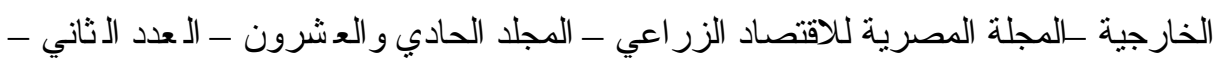

$$
\text { يونيو } 2011 .
$$

8- Deaton,A.and Muellbauer,J.,(1980),An Almost Ideal demand system American Econ,Rev, Vol.70,No 3,Jun,p 312-326

9- http://www.fao.or

10- http://contrade.un.org/db

11- Zellner,A.,(1962),An efficient method of Estimating seeminglg unrelated Regression and test for Aggregation Bias,journal of the American Statistical Association,p348-368. 
"ECONOMIC STUDY FOR THE PRODUCTION AND

MARKETING OF GARLIC CROP IN EGYPT

(STUDY CASE FOR BENI SUEF GOVERNORATE)" 